William \& Mary Law School

William \& Mary Law School Scholarship Repository

\title{
Split Definitive: How Party Polarization Turned the Supreme Court Into a Partisan Court
}

Neal Devins

William \& Mary Law School, nedevi@wm.edu

Lawrence Baum

Follow this and additional works at: https://scholarship.law.wm.edu/facpubs

Part of the Constitutional Law Commons, and the Supreme Court of the United States Commons

\section{Repository Citation}

Devins, Neal and Baum, Lawrence, "Split Definitive: How Party Polarization Turned the Supreme Court Into a Partisan Court" (2017). Faculty Publications. 1939.

https://scholarship.law.wm.edu/facpubs/1939

Copyright c 2017 by the authors. This article is brought to you by the William \& Mary Law School Scholarship Repository.

https://scholarship.law.wm.edu/facpubs 


\section{NEAL DEVINS AND \\ LAWRENCE BAUM}

\section{SPLIT DEFINITIVE: HOW PARTY}

\section{POLARIZATION TURNED THE SUPREME}

COURT INTO A PARTISAN COURT

Since 2010, when Elena Kagan replaced John Paul Stevens, all of the Republican-nominated Justices on the Supreme Court have been to the right of all of its Democratic-nominated Justices. ${ }^{1}$ This pattern is widely recognized, but it is not well recognized that it is unique in the Court's history. Before 2010, the Court never had clear ideological blocs that coincided with party lines.

Today's partisan split, while unprecedented, is likely enduring. The very political changes that underlie the current split make it likely that, for the foreseeable future, a Court with five Democratic-nominated

Neal Devins is Sandra Day O'Connor Professor of Law and Professor of Government, William and Mary Law School; Lawrence Baum is Professor Emeritus of Political Science, Ohio State University.

Authors' nOTE: 'Thanks to our research assistants Caitlin Cater, Peter Kyle, Barbara Marmet, and Amber Shepherd. Thanks also to participants at workshops at Cornell Law School, George Mason Law School, University of California-Berkeley Law School, and Vanderbilt Law School. Thanks too to Geof Stone for his thoughtful edits and to Josh Chafetz, Eric Clayes, Mike Dorf, Paul Edelman, Tara Grove, Peter Schuck, Mark Tushnet, and John Yoo for helpful comments.

${ }^{1}$ When classifying Justices as Democrats or Republicans we are referring to the party of the appointing president. We do so because presidential appointments of Justices are at the heart of our analysis of partisan polarization on the Court. As late as 1971, presidents would sometimes appoint Justices who were associated with a different political party than their own. For reasons detailed throughout this article, there is little prospect of cross-party appointments during the current era. 
Justices would reach decisions quite different from those a Court with five Republican-nominated Justices would reach. ${ }^{2}$ For this reason, presidential elections matter more for the Court than ever before.

Indeed, the Court was a focal point of the 2016 presidential campaign. Following the sudden death of Antonin Scalia, Democrats and Republicans divided over the propriety of President Obama's appointing a successor during an election year-exposing a deep, divisive gulf between the parties over the very issues that divide the Justices. ${ }^{3}$ Democratic candidates Hillary Rodham Clinton and Bernie Sanders spoke both of President Obama's constitutional responsibility to fill the Scalia seat and of their having a "litmus test" for Supreme Court nominees to overturn what Sanders called the "disastrous" Citizens United ruling, ${ }^{4}$ Republican candidates Donald Trump, Marco Rubio, Jeb Bush, and Ted Cruz backed Senate Republican efforts to block an Obama nominee, proclaimed the 2016 election a "referendum" on the Supreme Court, and spoke of the need for "future Supreme Court[s]" to undo the Roberts Court's decisions on the Affordable Care Act and same-sex marriage. ${ }^{5}$ Correspondingly, after

\footnotetext{
${ }^{2}$ For a sampling of post-2010 5-4 decisions along party lines, see note 62 .

${ }^{3}$ For discussions of the political import of Scalia's successor and the efforts of Republican Senators to block any Obama nominee to the Court, see How Antonin Scalia Cbanged America, Politico (Feb 14, 2016), archived at https://perma.cc/JP48-LREG; Michael D. Shear and Jennifer Steinhauer, More Republicans Say They'll Block Supreme Court Nomination, NY Times (Feb 15, 2016), archived at https://perma.cc/FPS9-SP23. Before Scalia's death, the Court was an emerging election issue; the advanced age of several Justices and the Court's politically charged docket contributed to its electoral significance. See Richard Wolf, Aging Supreme Court Energizes Republicans More than Democrats in 2016 Race, USA Today (Oct 25, 2015), archived at https://perma.cc/FC5A-F4SQ; Tony Mauro, SCOTUS $v$. Presidential Race, Natl L J (Jan 4, 2016), archived at https://perma.cc/HD9S-HFSX; Adam Liptak, Supreme Court Takes on Politically Charged Cases, NY Times (Oct 4, 2015), archived at https://perma.cc NZZ8D-4C'TB.

${ }^{4}$ John Wagner and Anne Gearan, Clinton, Sanders Agree on This Much in Colorado: GOP Shouldn't Wait on Scalia Replacement, Wash Post (Feb 13, 2016), archived at https://perma.ce /M5DQ-QXNJ; Martea Gold and Anne Gearan, Hillary Clinton's Litmus Test for Supreme Court Nominees: A Pledge to Overturn Citizens United, Wash Post (May 14, 2015), archived at https://perma.cc/6U4S-NEWT (quoting Sanders). Clinton also spoke of having a "bunch of litmus tests," including gay rights and the Voting Rights Act. See Jonathan Easley, Clinton: "I Have a Bunch of Litmus Tests" for Supreme Court Nominees, The Hill (Feb 3, 2016), archived at https://perma.cc/VEZ8-FPW9.

${ }^{5}$ Jonathan Martin, Republican Candidates Unite Against Obama Replacing Scalia, NY Times (Feb 13, 2016), archived at https://perma.cc/BRA5-BV3D; Liz Fields, Marco Rubio Says He Has a Plan to Make Gay Marriage Illegal Again, Vice News (Dec 14, 2015), archived at https:// perma.cc/H6ZR-TDKA (quoting Rubio); Bob Egelko, Trump, Rubio Weigh in on Supreme Court Ahead of Debate, San Francisco Chronicle (Dec 14, 2015), archived at https://perma.cc /HA2T-YFS3; Katie Zezima, Ted Cruz Calls for Fudicial Retention Elections of Supreme Court
} 
securing their party's nomination, Clinton and Trump continued to highlight the Republican-Democratic Supreme Court divide. They repeatedly called attention to the Court and, with it, party differences on gun control, immigration, health care, abortion, campaign finance, and voter identification laws. ${ }^{6}$

This article documents that today's Court is different from past Courts in the linkage between party and ideology. More important, it offers an explanation for this development. That explanation is based on the growth in polarization among political elites-polarization that has shaped the Court in multiple ways and that is likely to continue.

One key element of polarization is partisan sorting, in which conservatives increasingly migrate to the Republican Party and liberals to the Democratic Party. Among political elites, the ideological distance between Democrats and Republicans is perhaps greater today than at any other time in the nation's history. Because of partisan sorting, the party leaders who participate in the selection of Justices and the pools of prospective nominees to the Court are more ideologically homogeneous.

A second key element of polarization is growing ideological consciousness among the selectors of Justices and the Justices themselves. Political elites have become more sharply divided into ideological

7ustices, Wash Post (June 27, 2015), at https://www.washingtonpost.com/news/post-politics /wp/2015/06/27ted-cruz-calls-for-judicial-retention-elections-for-supreme-court-Justices/; Katie Zezima, Cruz Wants to Make 2016 a Referendum on the Supreme Court: He's Already Done It, Wash Post (Feb 15, 2016), at https://www.washingtonpost.com/news/post-politics/wp /2016/02/15/cruz-wants-to-make-2016-a-referendum-on-the-supreme-court-hes-already -done-it $/$ ?utm_term $=.793513 \mathrm{a} 5 \mathrm{caad}$.

${ }^{6}$ For general discussions of differences in party platforms and campaigns, see Melanie Mason and Chris Megerian, How the Democratic and Republican Party Platforms Stack Up on Climate Change, Iran, and More Key Issues, LA Times (July 27, 2016), available at http://www latimes.com/politics/la-na-pol-democrats-republicans-platforms-20160727-snap-htmlstory .html; Jonathan D. Salant, 10 Huge Differences Between Democratic and Republican Platforms, nj.com (July 28, 2016), available at http://www.nj.com/politics/index.ssf/2016/07/dnc_2016 10_big_ways_the_democratic_platform_diffe.html; Richard Wolf, Supreme Court Debate: Stark Contrasts Emerge Between Trump, Clinton, USA Today (Oct 20, 2016), available at http://www.usatoday.com/story/news/politics/elections/2016/10/20/supreme-court-debate -clinton-trump-guns-abortion/92452362; Dahlia Lithwick and Mark Joseph Stern, Who Will Protect the Constitution? Donald Trump ws. Hillary Clinton, Amendment by Amendment, Slate (Oct 30, 2016), available at http://www.slate.com/articles/news_and_politics/jurisprudence /2016/10/who_will_protect_the_constitution_donald_trump_or_hillary_clinton.html.

${ }^{7}$ Measures of congressional voting patterns show that the ideological distance between Democrats and Republicans is greater today than at any other time in our nation's history (see fig. 3); see generally Daryl J. Levinson and Richard H. Pildes, Separation of Parties, Not Powers, 119 Harv L Rev 2311 (2006). 
camps that view each other with hostility, a process that has been labeled affective polarization. ${ }^{8}$ In part, this development is tied to the ideological sorting of Democrats and Republicans. ${ }^{9}$ Affective polarization does not necessarily mean that conservatives and liberals are farther apart than they were in the past. Rather, it means that individuals are more conscious of being in an ideological camp that is opposed to the competing camp.

We analyze the impact of political polarization on the Court largely in terms of elite social networks. Polarization is reflected in the social networks that are critical to grooming and identifying appointees to the federal courts, including the Supreme Court. ${ }^{10}$ It also pervades the social networks of which the Justices themselves are a part; conservative Republican-appointed Justices interact with elites who support conservative outcomes and liberal Democratic-appointed Justices interact with elites who support liberal outcomes. ${ }^{11}$

In highlighting the profound impact of party polarization on today's Court, we contrast the current period with earlier periods. Even a few decades ago, the world in which the Justices lived and worked was more homogeneous than it is today, with a center-left tilt among academic and media elites. This social environment probably helps to account for an apparent drift to the left by Republicanappointed Justices such as John Paul Stevens, David Souter, and especially Harry Blackmun. ${ }^{12}$ Today, the elite world has become ideo-

\footnotetext{
${ }^{8}$ See Shanto Iyengar, Gaurav Sood, and Yphtach Lelkes, Affect, Not Ideology: A Social Identity Perspective on Polarization, 76 Pub Opinion Q 405, 406 (2012); Patrick R. Miller and Pamela Johnston Conover, Red and Blue States of Mind: Partisan Hostility and Voting in the United States, 68 Pol Research Q 225 (2015). Affective polarization is also seen in the increasing acrimony between members of opposition parties on talk shows and on the floor of Congress. See Danny Hayes, The Words Hurt Model of Polarization, Wash Post (Jan 6, 2013), archived at https://perma.cc/57YS-3GZ8.

'Cass R. Sunstein, Partyism Now Trumps Racism, Bloomberg View (Sept 22, 2014), archived at https://perma.cc/4CQW-FY9E.

${ }^{10}$ For an insightful treatment of efforts by the Reagan Justice Department to groom young conservatives for judgeships, see Steven Teles, Transformative Bureaucracy: Reagan's Lanvyers and the Dymamics of Political Investment, 23 Studies in Am Pol Dev 61 (2009).

"On the importance of these social networks to judicial decision making, see Section IV.A. See generally Lawrence Baum, Judges and Their Audiences: A Perspective on Fudicial Bebavior (Princeton, 2006).

${ }^{12}$ See Lawrence Baum and Neal Devins, Why the Supreme Court Cares about Elites and Not the American People, 98 Georgetown L J 1515, 1574-79 (2010). 'To a degree, the appearance of a movement to the left by Justices such as Blackmun and Stevens is a product of the rightward movement of the Court as a whole with the appointments of new Justices. Indeed, Stevens and (to a lesser degree) Blackmun cited that rightward movement as the source of
} 
logically polarized, so that Justices on both the left and right are part of social networks that reinforce conservatism for Republicanappointed Justices and liberalism for Democratic-appointed Justices. Of particular importance, conservative elites have consciously sought to overcome what they see as a liberal bias in the legal system, including the courts. That effort is reflected in the rise of the Federalist Society and the related establishment of a conservative legal network. ${ }^{13}$

Our analysis does not speak to how liberal a Court with a Democratic-appointed majority would be or how conservative a Court with a Republican-appointed majority would be, because a range of circumstances can affect the Court's ideological center of gravity. ${ }^{14}$ But the changes in the Court that we describe have had a tendency to move it to the right, because Republican appointees on the whole are now more conservative than in the past while Democratic appointees as a group have not changed appreciably. ${ }^{15}$ Our analysis shows that

their apparent change. Jeffrey Rosen, Interview Transcript: Fustice fobn Paul Stevens, NY Times Magazine (April 12, 2010); Moyers \& Company, In Search of the Constitution: Mr. Fustice Blackmun, April 16, 1987, at http://billmoyers.com/content.mr-Justice-blackmun -supreme-court/. However, several appointees of Republican presidents who joined the Court between 1953 and 1990 showed a movement to the left during their Court tenure based on their votes on case outcomes even with controls for the voting of the same colleagues over time. Baum, Fudges and Their Audiences at 148 (cited in note 11). Rates of agreement with the same opinions show a similar pattern. For instance, Blackmun agreed with Chief Justice Burger 23 percentage points more often than he agreed with Justice Brennan in the 1970-79 Terms but agreed with Brennan 12 percentage points more often than with Burger in the 1980-85 Terms; Stevens agreed with Brennan 1 percentage point more often than with Justice Rehnquist in the 1976-78 Terms and 14 percentage points more often in the 1979-85 Terms; Souter agreed with Justice Scalia 11 percentage points more often than with Stevens in the 1990-92 Terms but agreed with Stevens 21 percentage points more often than with Scalia in the 1993-2004 Terms. Agreement rates were calculated from data in The Statistics, Harv L Rev, published annually in the November issue.

${ }^{13}$ See Steven M. Teles, The Rise of the Conservative Legal Movement: The Battle for Control of the Law (Princeton, 2008); Amanda Hollis-Brusky, Ideas with Consequences: The Federalist Society and the Conservative Counterrevolution (Oxford, 2015).

${ }^{1+}$ Today's Court does not have a sharper conservative-liberal divide than past Courts; what distinguishes it is that ideological divisions coincide with partisan divisions. On trends in ideological polarization, see Tom S. Clark, Measuring Ideological Polarization on the United States Supreme Court, 62 Pol Research Q 146 (2009); Donald Michael Gooch, Ideological Polarization on the Supreme Court: Trends in the Court's Institutional Environment and Across Regimes, 1937-2008, 43 Am Pol Research 999 (2015).

${ }^{15}$ In Part I, we highlight how it is that today's Democrats are all moderate liberals as compared to earlier Courts where there were strong liberal Democrats as well as more conservative Democrats. In Part II, we link this phenomenon to the appoinument strategies of Democratic presidents. In so doing, we explain why Democrats on today's Court are about 
the growing ideological gap between Democratic-appointed Justices and Republican-appointed Justices is largely attributable to the appointment of conservative Republican nominees. ${ }^{16}$

In this article we point to the ways that polarization in the larger world of political and social elites has reshaped the Court. But in doing so, we do not ignore the differences between the Court and the other branches. ${ }^{17}$ For one thing, the Justices' partial insulation from partisan constituencies gives them more freedom to depart from the ideological positions that those constituencies subscribe to in particular cases, and their embrace of the norm of judicial independence enhances that freedom. ${ }^{18}$ Further, the Justices' preference for consensus where it is possible reduces the impact of ideological divisions on some decisions. ${ }^{19}$

Finally, and perhaps most important, Justices decide cases in legal terms. As a result, ideological considerations often do not figure into the Court's decision making. ${ }^{20}$ Then-Senator Barack Obama underlined this reality when he voted against confirmation of Chief Justice John Roberts not because of the "95 percent of the cases" that

equally liberal as those on earlier Courts but less ideologically diverse (see figs. 1 and 2). See also David Strauss, The Last Liberal fustice?, 21 Democracy 114 (2011) (noting that some liberals think there "have been no truly progressive Justices on the Court for many years"); Jeffrey Rosen, What's a Liberal fustice Now??, NY Times Magazine, MM50 (May 26, 2009) (noting differences between Warren-era liberalism and liberalism today).

${ }^{16}$ See Section IV.C.

${ }^{17}$ Thomas Keck has presented evidence that on four sets of controversial issues, voting differences between Republicans and Democrats in Congress are substantially greater than voting differences in the Supreme Court and the federal courts of appeals. Thomas Keck, fudicial Politics in Polarized Times 147-50 (Chicago, 2014).

${ }^{18}$ Justice Antonin Scalia, for example, took great pride in casting "liberal" votes on flag burning, search and seizure, and other issues because of his commitment to a set of interpretive principles that transcend ideology. See Margot Talbot, Supreme Confidence, New Yorker (Mar 28, 2005), archived at https://perma.cc/E7GC-HUMT. Correspondingly, to the extent that today's Justices have an incentive to demonstrate that partisanship does not impact their decision making, the partisan divide on today's Court may moderate Court decision making in ways that the earlier conservative-liberal divide did not moderate decision making. For a general treatment of this topic, see Lawrence S. Wrightsman, The Psycbology of the Supreme Court 111-15 (Oxford, 2006).

1" See Pamela C. Corley, Amy Steigerwalt, and Artemus Ward, The Puzzle of Unanimity: Consensus on the United States Supreme Court 161 (Stanford Law Books, 2013); Cass R. Sunstein, Unanimity and Disagreement on the Supreme Court, 100 Cornell L Rev 769 (2015).

${ }^{20}$ For a provocative study on how Roberts Court Justices are divided on methodological as well as ideological grounds (and how it is that methodological preferences sometimes prevail), see Joshua B. Fischman and Tonja Jacobi, The Second Dimension of the Supreme Court, 57 Wm \& Mary L Rev 1671 (2016). 
would be decided as a matter of law but because of the "5 percent of cases that are truly difficult." ${ }^{21}$

For those reasons, we do not expect the Justices always to cast votes that match their ideological and partisan affiliations. Chief Justice Roberts's votes in both the 2012 and 2015 Affordable Care Act decisions are prominent examples, ${ }^{22}$ but these votes do not mean that the Chief Justice is a moderate or a liberal; he is clearly a conservative. ${ }^{23}$ Likewise, just because the Justices sometimes issue unanimous opinions on issues that divide conservatives and liberals outside the Court does not mean that today's Court transcends partisan labels. ${ }^{24}$ Republican-appointed Justices are conservative notwithstanding the fact that all nine Justices agreed that the police cannot search digital information on a cellphone without a warrant; correspondingly, Democratic-appointed Justices are liberal notwithstanding the Court's unanimous ruling that the Constitution excludes ministers from the protections of employment discrimination laws. ${ }^{25}$

\footnotetext{
${ }^{21}$ Nomination of John Roberts, 109th Cong, 1st Sess (Sept 22, 2005), in 151 Cong Rec 21032 (remarks of Senator Obama); Mark Tushnet, In the Balance: Law and Politics on the Roberts Court xiv (W. W. Norton, 2013) (expressing agreement with Obama).
}

${ }^{22}$ National Federation of Independent Business v Sebelius, 132 S Ct 2566 (2012); King v Burvell, 135 S Ct 2480 (2015). See David G. Savage, Chief Justice Roberts Signals That Supreme Court Remains Independent, LA Times A1 (June 30, 2012).

${ }^{23}$ See notes 252-57 and accompanying text. For identical reasons, Justices Stephen Breyer and Elena Kagan are clearly liberal notwithstanding the fact that they joined the Court's Republicans in finding the Affordable Care Act's Medicaid extension unconstitutional.

${ }^{24}$ See generally Sunstein, 100 Cornell L Rev (cited in note 19).

${ }^{25}$ Riley $v$ California, 134 S Ct 2473 (2014) (cell phone searches); Hosanna-Tabor Evangelical Lutheran Church \& School v EEOC, 132 S Ct 694 (2012) (recognizing ministerial exception to employment discrimination legislation). Moreover, the Court sometimes masks deep divisions among the Justices by issuing narrow unanimous or near-unanimous rulings that defer decision on deeply divisive issues. Examples include the Court's unanimous 2009 ruling in Nortbwest Austin Municipal Utility District No. 1 v Holder, 557 US 193 (2009) (deferring decision on the constitutionality of the preclearance requirements of the Voting Rights Act), the Court's 7-1 ruling in Fisher v University of Texas, 133 S Ct 2411 (2013) (deferring decision on University of 'Texas affirmative action program), and the Court's unanimous ruling in Zubik v Burwell, 136 S Ct 1557 (2016) (inviting the parties to resolve a dispute over contraceptive coverage in certain health plans). Some unanimous rulings feature sharp disagreements on doctrinal matters. Examples include McCullen v Coakley, 134 S Ct 2518 (2014) (allowable regulation of protest activities at abortion clinics), NLRB v Noel Caming, 134 S Ct 2250 (2014) (scope of presidential recess appointment power), and Bond v United States, 134 S Ct 2077 (2014) (reach of federal power to implement treaties through legislation). The proportion of unanimous decisions in recent terms is typically between 40 and 50 percent, and it was about two-thirds in the 2013 Term. See Statistics, SCOTUSblog, http://www.scotusblog.com/statistics/. This frequent agreement among the Justices underlines the difference between the Supreme Court and Congress noted in this paragraph. 
This article is organized as follows: Part I documents that the contemporary Court is the first Court to be divided sharply along partisan lines by examining historical patterns of division on the Court. Part II examines the growth in polarization in government and in the broader political elite. It also points to the implications of that polarization for the Court.

The remainder of the article examines those implications in greater detail. Part III examines how polarization has affected the appointments of Supreme Court Justices. It emphasizes differences in the appointment strategies of Democratic and Republican presidents, differences that reflect the rise of the conservative legal movement and its impact on the grooming and identification of conservative nominees. It therefore explains why Republican appointees to the Court in the current era are distinctly more conservative as a group than their predecessors, while today's Democratic appointees are about as liberal as their predecessors. ${ }^{26}$

Part IV turns to sitting Justices. It uses social psychology to explain further why today's party polarization has resulted in partisan voting patterns by the Justices, focusing on the impact of elite social networks in judicial decision making. Here, too, we probe differences between the parties. During the 1960s through 1980s, the dominant legal elite culture pushed Republican-appointed Justices away from the right and toward the center-left. Today, however, Justices are less prone to drift and, with no post-1990 Republican-appointed Justice moving to the center-left, there has been a hardening of the right.

Part $\mathrm{V}$ briefly considers the ramifications of all this: why presidential elections matter more for the Court today than ever before; why the Court is likely to move more sharply to the right or left depending on whether there is a majority of Democratic or Republican appointees; and, correspondingly, why-after Justice Kennedythere is not likely to be a "super-median" Justice 27 who sometimes sides with conservatives and other times with liberals in the Court's most divisive opinions.

Following Part $\mathrm{V}$, we will consider how the nomination and confirmation of Neil Gorsuch reinforce our central claim.

\footnotetext{
${ }^{26}$ See figure 2 (comparing historic means of Democratic and Republican appointees).

${ }^{27}$ Lee Epstein and Tonja Jacobi, Super Medians, 61 Stan L Rev 37 (2008).
} 


\section{Party and Ideology in Supreme Court History}

On the current Supreme Court, ideological lines coincide with party lines: since Elena Kagan succeeded John Paul Stevens in 2010, every Justice who was appointed by a Democratic president has had a more liberal voting record than every Republican appointee. In the 2010-15 Terms of the Court, the Justice appointed by a Democratic president who cast the highest proportion of conservative votes (43.5 percent) was Stephen Breyer; the Justice appointed by a Republican president who cast the lowest proportion of conservative votes (53.4 percent) was Anthony Kennedy..$^{28}$

The coincidence of party and ideology on today's Court has been widely noted, ${ }^{29}$ but the departure from traditional patterns on the Court is not as well recognized. This is the first period in which the Court has been sharply divided between substantial blocs of Justices from each of the two major political parties. To demonstrate this difference, we will analyze ideological differences among Justices over time. We divide our analysis into two periods: 1801-1937 and 1937-2016. During the first period, ${ }^{30}$ we look principally to historical studies of the Court and our own analysis of dissenting opinions in landmark cases. For the 1937-2016 period, we look primarily to Martin-Quinn scores, which are available beginning with the 1937 Term, as measures of the Justices' ideological positions. ${ }^{31}$

${ }^{28}$ These percentages are based on analysis of data in the Supreme Court Database, http:// scdb.wustl.edu/. We analyzed cases decided after oral argument (decision type $=1,6$, or 7). The criteria for coding votes as liberal or conservative are described at http://scdb.wustl.edu /documentation.php?var = decisionDirection.

A similar pattern exists for the Martin-Quinn scores, in which higher scores indicate greater conservatism. In the mean Martin-Quinn scores across the 2010-14 Terms, Justice Kennedy had the lowest score for a Republican at +0.07 ; Justice Breyer had the highest score for a Democrat at -1.41 ; the nine Justices' scores ranged from +3.14 to -2.34 . See table 1 for a detailing of Justices' rankings by Martin-Quinn scores over time; for additional discussion of Martin-Quinn scores, see note 31.

${ }^{29}$ See, for example, Greg Stohr, Roberts Supreme Court's Partisan Split Shows New fustices Are Predictable, Bloomberg News (July 1, 2011), at http://www.bloomberg.com/news/2011 -07-01/roberts-supreme-court-s-partisan-split-shows-new-Justices-are-predictable.html; Adam Liptak, The Polarized Court, NY Times, SR1 (May 11, 2014) (discussing, inter alia, findings in an earlier version of the study that is the basis of this article).

${ }^{30}$ We do not consider the $1789-1800$ period, a time when the Court was headed by three different Chief Justices and issued very few opinions and when all the Justices were appointed by Federalist presidents.

${ }^{31}$ The Martin-Quinn scores are based on a transformation of the patterns of interagreement on votes among the Justices, without a priori labeling of their ideological direction and with a procedure that is designed to minimize the impact of random fluctuations in the Jus- 


\section{A. THE PERIOD BEFORE I937}

Throughout the period that ended in 1937, there is little evidence of partisan division within the Court. Indeed, it is difficult to trace patterns of division at all. Dissent was infrequent, and the Justices typically spoke with one voice (issuing unanimous opinions for the Court) ${ }^{32}$ In part, this reflected the common practice of suppressing dissenting views in the Court's final votes on the merits. ${ }^{33}$ Moreover, as in the federal courts of appeals today, ${ }^{34}$ many of the mandatory cases that constituted a large share of the Court's docket until 1925

tices' voting from term to term that results from the specific mix of cases that the Court hears. The procedure was first set out in a 2002 article and is widely used in research on the Supreme Court. See Andrew D. Martin and Kevin M. Quinn, Dynamic Ideal Point Estimation via Markov Chain Monte Carlo for the U.S. Supreme Court 1953-1999, 10 Pol Analysis 134 (2002); Brandon Bartels, The Constraining Capacity of Legal Doctrine on the U.S. Supreme Court, 103 Am Pol Sci Rev 474 (2009); Lee Epstein and William M. Landes, Was There Ever Sucb a Tbing as 7udicial Self-Restraint?, $100 \mathrm{Cal}$ L Rev 557 (2012); William M. Landes and Richard A. Posner, Rational 7udicial Bebavior: A Statistical Study, 1 J Legal Analysis 775 (2010). It should be noted that the Martin-Quinn scores are not fully linear, so that the distances between different pairs of Justices are not necessarily comparable. Daniel E. Ho and Kevin M. Quinn, How Not to Lie with Fudicial Votes: Misconceptions, Meastrement, and Models, 98 Cal L Rev 813, 846-47 (2010).

We use the Martin-Quinn scores rather than scores based on ideological coding of votes in the Supreme Court Database because they extend several terms further than the currently available data in the database (the 1937 Term rather than the 1946 Term) and because their properties make them somewhat better indicators of the Court's ideological lineup. A division at the 1937 Term is sensible for another reason: 1937 is considered the start of the modern Court. In 1937, the "old Court" acquiesced to the New Deal and Franklin Delano Roosevelt was able to appoint his first (out of eight) Supreme Court Justice. See William E. Leuchtenburg, The Supreme Court Reborn: The Constitutional Revolution in the Age of Roosevelt (Oxford, 1996). The year 1937 also corresponds to Congress's decision to grant the Court discretionary certiorari power in 1925, legislation that allowed the Court to assume a broader role expounding legal principles. See Tara Leigh Grove, The Exceptions Clause as a Structural Safeguard, 113 Colum L Rev 929, 931-32, 948-78 (2013). For other prominent academic studies that treat 1937 as the transformative year separating the old Court from the modern Court, see Bruce Ackerman, We the People: Foundations (Belknap, 1993); Thomas M. Keck, The Most Activist Supreme Court in History (Chicago, 2004).

${ }^{32}$ In the period from 1801 through 1938 , at most there were four terms in one era (1836, $1845,1852,1854)$ in which more than 20 percent of the Court's decisions included dissenting opinions. Lee Epstein et al, The Supreme Court Compendium: Data, Decisions and Developments 227-30 (CQ Press, 4th ed 2007). See also Sunstein, 100 Cornell L Rev at 773-84 (cited in note 19$)$.

${ }^{33}$ Alexander M. Bickel, The Unpublished Opinions of Mr. Fustice Brandeis: The Supreme Court at Work (Harvard, 1957); Lee Epstein et al, The Norm of Consensus on the U.S. Supreme Court, 45 Am J Pol Sci 362 (2001); Robert Post, The Supreme Court Opinion as Institutional Practice: Dissent, Legal Scholarship, and Decisionmaking in the Taft Court, 85 Minn L Rev 1267, 1331-55 (2001).

${ }^{34}$ Harry T. Edwards and Michael A. Livermore, Pitfalls of Empirical Studies That Attempt to Understand the Factors Affecting Appellate Decisionmaking, 58 Duke L J 1895, 1950-58 (2009). 
were "easy" and therefore unlikely to provoke disagreement among the Justices.

When the Justices did disagree, those disagreements did not tend to break along party lines. ${ }^{35}$ One piece of evidence for the lack of polarization can be derived from a listing of the Court's most important decisions in the Guide to the U.S. Supreme Court. ${ }^{36}$ Of the seventy-five most important decisions between 1790 and 1937 in which there were at least two dissenting votes, in only one were all of the Justices on one side appointed by presidents of one party and all of the Justices on the other side appointed by presidents of the other party. ${ }^{37}$ Consider, for example, two of the most noteworthy cases from this period, Dred Scott v Sandford (1857) and Lochnerv New York (1905). In Dred Scott, the two dissenters were the Whig-appointed Benjamin Curtis and the Democratic-appointed John McLean; ${ }^{38}$ in Locbner, Justices appointed by both Democratic and Republican presidents were in both the majority and the dissent, and Justices

\footnotetext{
${ }^{35}$ Prior to 1910 , there is little research that systematically analyzes disagreements among the Justices. The Legacy Supreme Court Database includes data on the Justices' votes in all decisions in the 1790-1945 Terms. From the late 1860s on, there were enough nonunanimous decisions to allow meaningful analysis of voting patterns. When the Justices' votes in the nonunanimous decisions are characterized in terms of the database coding of ideology, there were no terms between 1867 and 1909 in which there were at least two Justices appointed by presidents of each party and all the Justices from one party had more liberal records than all the Justices from the other party. 'This finding should not be given undue weight, because the numbers of nonunanimous decisions that could be coded as liberal or conservative were as low as nine or ten in some terms and because the definitions of liberal and conservative positions in the current era do not necessarily capture possible lines of division in the late nineteenth century. The database and its definitions of liberal and conservative positions are cited in note 28.

${ }^{36}$ David G. Savage, Guide to the U.S. Supreme Court 1276-94 (CQ Press, 5th ed 2010). The criteria for selection of important cases were not made explicit in the successive editions of the Guide, and there are biases and idiosyncrasies in that selection. Still, the list in the Guide is a good and substantial sampling of decisions that can be considered important, and it is unique in covering the full history of the Supreme Court. For evaluations of the list, see Saul Brenner, Majority Opinion Assignment in Salient Cases on the U.S. Supreme Court: Are New Associate fustices Assigned Fewer Opinions?, 22 Just Sys J 209, 212 n 4 (2001); Beverly Blair Cook, Measuring the Significance of U.S. Supreme Court Decisions, 55 J Pol 1127, 1132, 1136 (1993); Lee Epstein and Jeffrey A. Segal, Measuring Lssue Salience, 44 Am J Pol Sci 66, 68-71 (2000).

${ }^{37}$ That decision was United States $v$ Texas, 143 US 621 (1892). The dissenters were Democrats Melville Fuller and Lucius Lamar.

${ }^{38} 19$ How 393 (1857). Dred Scott was hardly an anomaly. Even during Reconstruction (when the parties were highly polarized), Republicans and Democrats joined together to issue unanimous decisions on major postwar issues. See Ex Parte McCardle, 7 Wall 506 (1869); Mississippi v fohnson, 4 Wall 475 (1867).
} 
John Harlan and Oliver Wendell Holmes broke ranks with the other Republican-appointed Justices in voting to uphold the challenged economic regulation. ${ }^{39}$

Quantitative analyses of the Justices' voting behavior are available for the full period beginning with the Court's 1910 Term. ${ }^{40}$ Donald Carl Leavitt's study of the White Court (1910-21) used the Justices' votes to calculate scores on ideological scales for the 1910-15 and 1916-20 Terms. In neither period were the Court's Republican- and Democratic-appointed Justices separated from each other ideologically; most notably, Democratic president Woodrow Wilson's appointee James McReynolds (1914-41) took positions that were relatively and increasingly conservative. ${ }^{41}$

Eloise C. Snyder tracked agreements and disagreements among the Justices and used analysis of votes to identify what she called ideological "cliques" for each "natural Court" from 1921 to $1937.4^{43}$ At no time were all the Justices appointed by Democratic presidents in separate cliques from all the Justices appointed by Republican presidents. ${ }^{4+}$ In cases dealing with New Deal programs that sharply

\footnotetext{
${ }^{30} 198$ US 45 (1905). See also Owen M. Fiss, Oliver Wendell Holmes Devise History of the United States Supreme Court: Troubled Beginnings of the Modern State, 1888-1910, 35 (Cambridge, 1993) (concluding that there was no ideological divide between Democrats and Republicans of this period).

${ }^{40}$ These analyses begin with agreements and disagreements of the Justices in individual cases and use statistical techniques to place each Justice on a unidimensional scale for particular time periods. Although the votes used in these analyses are not labeled ideologically, the scales can be interpreted in ideological terms because patterns of agreement and disagreement tend to reflect a dominant ideological dimension. See Bernard Grofman and Timothy J. Brazill, Identifying the Median fustice on the Supreme Court Through Multidimensional Scaling: Analysis of "Natural Courts" 1953-1991, 113 Pub Choice 55 (2002).

${ }^{41}$ Donald Carl Leavitt, Attitudes and Ideology on the White Supreme Court 1910-1920, *186 (PhD dissertation, Michigan State University, 1970). Leavitt undertook several dimensional analyses of the Justices' votes; we relied primarily on the first principal axis loading in Qanalyses of votes. Another analysis of voting in the 1916-21 Terms found a similar pattern. Roger Handberg, Decision-Making in a Natural Court, 1916-1921, 4 Am Pol Q 357, 365 (1976). Chief Justice White might be classified as a Democrat because of his own party affiliation and his initial appointment by President Cleveland, or as a Republican because of his elevation to Chief Justice by President William Howard Taft. In Leavitt's analysis, White stood somewhat to the left among his colleagues in the 1910-15 Terms and somewhat to the right in the 1916-21 Terms.

${ }^{42}$ A natural Court is a period during which the Court's membership is unchanged.

${ }^{43}$ Eloise C. Snyder, The Supreme Court as a Small Group, 36 Soc Forces 232, 235 (1958). The Snyder study, based on a subset of cases, extended to 1953.

${ }^{44}$ The best known of the natural Courts in that period was the Court that sat in the 193236 Terms, the one that collectively came into severe conflict with President Franklin Roosevelt during his first term in office. That Court split along lines that cut across party.
} 
divided the Court, the Court's two Democratic-appointed Justices (Louis Brandeis and James McReynolds) were in opposing camps and the Justices appointed by Republican presidents were also divided. ${ }^{45}$

Without question, then, Supreme Court decision making transcended party-line divisions throughout the 1801-1937 period. That is not to say that party identity was irrelevant to the Court's decision making; ${ }^{46}$ presidents sometimes appointed Justices with an eye toward advancing their party's policy agenda. ${ }^{47}$ Nonetheless, all available evidence suggests that the Court's decision making did not track party lines.

\section{B. THE PERIOD SINCE I937}

For the period beginning with the 1937 Term, the Martin-Quinn scores can be used to trace the relationship between party and ideology by allowing us to array the Justices from left to right in each term of the Court. As these arrays show, before 2010 the Court never divided along strictly partisan lines. It came closest to a full split between Republican and Democratic appointees in the 1941-44 Terms. Seven of the nine Justices had been appointed by Democrat Franklin Roosevelt; Owen Roberts and Chief Justice Harlan Fiske Stone had been appointed by Republican Calvin Coolidge (although Stone had been elevated to Chief Justice by Roosevelt). Throughout that period, Roberts was the Court's most conservative Justice. In all but one of the four terms (and in 1945), Stone was more conservative than any of the Justices who had initially been appointed by Roosevelt. But the differences between him and the most conserva-

The well-known alignments of that period are documented in Snyder, 36 Soc Forces at 235 (cited in note 43), and C. Herman Pritchett, The Roosevelt Court: A Study in fudicial Politics and Values 1937-1947, 32, 34, 242 (Macmillan, 1948).

${ }^{45}$ See, for example, National Labor Relations Board v Fones \& Langblin Steel Corp., 301 US 1 (1937) (upholding National Labor Relations Act of 1935); United States v Butler, 297 US 1 (1936) (declaring Agricultural Adjustment Act of 1933 unconstitutional); Railroad Retirement Board v Alton Railioad Co., 295 US 330 (1935) (declaring Railroad Retirement Act of 1934 unconstitutional).

${ }^{46}$ For example, in the major cases that arose from secession and President Lincoln's policies during the Civil War, the Court's Republicans generally were more favorable to the Union's position than were its Democrats.

${ }^{47}$ One famous example is President U. S. Grant's appointment of two Supreme Court Justices (Joseph Bradley and William Strong) who supported Grant's view that paper money was constitutional. With the backing of Bradley and Strong, the Court in 1871 voted 5-4 to overturn an 1870 case that ruled that the federal government was without authority to issue paper money. Knox v Lee, 79 US 457 (1871) (overturning Hepburn v Griswold, 75 US 603 (1870)). 
tive Roosevelt appointee in each of those terms, as measured by the Martin-Quinn scores, were small. ${ }^{48}$

Unlike today's partisan divide, there was widespread agreement among the Justices on issues that had previously divided the Court. Stone and Roberts, for example, joined the Court's Democraticappointed Justices in Wickard $v$ Filburn, ${ }^{49}$ embracing an extraordinarily broad interpretation of Congress's Commerce Clause power. More telling, there was wide divergence among the Martin-Quinn scores of the seven Democratic-appointed Justices on the 1941-44 Court. ${ }^{50}$ In particular, there were sharp conflicts over civil rights and civil liberties issues. ${ }^{51}$ Furthermore, it was in the Stone Court, beginning in 1941, that dissenting votes and dissenting and concurring opinions began to proliferate. ${ }^{52}$ In several landmark rulings involving the First Amendment rights of Jehovah's Witnesses, for example, the Court's Democratic-appointed Justices were bitterly divided. ${ }^{53}$ Beyond disagreements over legal doctrine, enmity among the Roosevelt

\footnotetext{
${ }^{48}$ To the extent that the Court's ideological division in that period coincided with party lines, it should be noted that it is considerably more likely mathematically that these lines will coincide when only two Justices are from the minority party, and even more likely when there is one Justice from that party, than when the partisan division is 6-3 or 5-4. For example, the odds of two specific Justices out of nine randomly standing to the right of all their colleagues is 1 in 36; the odds of four out of nine is 1 in 126.

4" 317 US 111 (1942). For an illuminating discussion of internal Court deliberations (revealing that Democrats such as Robert Jackson were especially concerned about the reach of the decision), see Barry Cushman, Formalism and Realism in Commerce Clause furisprudence, 67 U Chi L Rev 1089 (2000).

${ }^{50}$ The range of Martin-Quinn scores among the four Democrats in the 2010 Term was .678; in the 2011 Term, it was .947. In contrast, the ranges among the seven Democrats in the 1941-44 Terms were, successively, 3.489, 3.475, 3.349, and 3.095. Ranges of MartinQuinn scores should be interpreted with caution, because the scores are not on a fully linear scale (see Ho and Quinn, $98 \mathrm{Cal} \mathrm{L} \mathrm{Rev} \mathrm{at} \mathrm{846-47),} \mathrm{but} \mathrm{the} \mathrm{differences} \mathrm{are} \mathrm{nonetheless}$ striking.

${ }^{51}$ See generally, Leuchtenburg, The Supreme Court Reborn (cited in note 31) (noting divisions within New Deal Court on civil rights and liberties).

${ }^{52}$ See Thomas G. Walker, Lee Epstein, and William J. Dixon, On the Mysterious Demise of Consensual Norms in the United States Supreme Court, $50 \mathrm{~J}$ Pol 362 (1988).

${ }^{53}$ In Murdoch v Pennsylvania, 319 US 105 (1943), the Court struck down a city ordinance with licensing and tax requirements for door-to-door sales as applied to the activities of Jehovah's Witnesses. Id (overruling fones v Opelika, 316 US 584 (1942)). The dissenters included not only Republican appointee Owen Roberts but also Roosevelt appointees Felix Frankfurter, Stanley Reed, and Robert Jackson. In West Virginia State Board of Education v Barnette, 319 US 624 (1943), the Court held that compulsory participation of public school students in flag salute ceremonies violated First Amendment Rights of Jehovah's Witnesses. Id (overruling Minersville Sch. Dist. v Gobitis, 310 US 586 (1940)). Democratic appointees Roberts, Frankfurter, and Reed dissented.
} 
appointees reached a level that has had few if any parallels in the Court's history. ${ }^{54}$

The Warren Court illustrates the complicated relationship between party and ideology throughout this period. President Harry Truman's four appointees ${ }^{55}$ all developed relatively conservative records on the Court, while Eisenhower appointees Earl Warren and William Brennan were distinctly more liberal. Correspondingly, in the decisions that sharply divided the Court, both majority and minority coalitions typically had representatives from both parties. In Miranda $v$ Arizona, ${ }^{56}$ for instance, the majority consisted of two Republican- and three Democratic-appointed Justices, while the dissenters included two Republican- and two Democratic-appointed Justices. ${ }^{57}$

The relationship between party and ideology remained complicated in the Burger and Rehnquist Courts. Based on the MartinQuinn scores, Brennan was one of the two most liberal Justices in each of his last twenty terms on the Court, from 1970 to 1990. President Gerald Ford's appointee John Paul Stevens was to the left of the Court's center throughout his tenure from 1975 to 2010, and from 1991 to 2010 he was the most liberal Justice. President George H. W. Bush's appointee David Souter was at the center of the Court in the 1991 Term, his first year as a Justice, and to the left of center for the remainder of a tenure that ended in 2009. For his part, John Kennedy's appointee Byron White was near the Court's ideological center throughout his tenure on the Court from 1962 to 1993, and during the Burger and Rehnquist Courts he stood to the right of Brennan, Stevens, and (from the 1979 Term on) Harry Blackmun, a Richard Nixon appointee.

As in the period from 1790 to 1937 , the lack of a partisan divide in the Court from 1938 to 2010 is underlined by the divisions of the

\footnotetext{
${ }^{54}$ See Noah Feldman, Scorpions: The Battles and Triumphs of FDR's Great Supreme Court Fustices (Grand Central, 2010); H. N. Hirsch, The Enigma of Felix Frankfurter 127-200 (Basic Books, 1981).

${ }_{55}$ Those appointees were Chief Justice Fred Vinson (appointed in 1946), Harold Burton (1945), Tom Clark (1949), and Sherman Minton (1949).

56 384 US 436 (1966).

${ }^{57}$ Justices in the majority were Roosevelt appointees Hugo Black and William O. Douglas, Eisenhower appointees Earl Warren and William Brennan, and Johnson appointee Abe Fortas. The dissenters were Truman appointee Tom Clark, Kennedy appointee Byron White, and Eisenhower appointees John Harlan and Potter Stewart.
} 
Justices in important cases. ${ }^{58}$ Of the 322 cases in that period that the Guide to the U.S. Supreme Court lists as important and in which at least two Justices dissented ${ }^{59}$ only one case divided all the Court's Republican-appointed Justices from all of their Democratic-appointed colleagues (and that decision is itself ambiguous). ${ }^{60}$ That is a remarkable record.

But even while the Court continued to be without a sharply partisan division, the conditions for such a division were developing through the appointment process. Byron White, appointed by President Kennedy in 1962, was the last moderate-to-conservative Democratic appointee. David Souter, appointed by George H. W. Bush in 1990, was the last moderate-to-liberal Republican appointee. We will discuss the changes in presidential appointment strategies in Part III. For now, we simply note that these changes created the preconditions for an ideological division on the Court that coincided with party.

We have described the partisan division between substantial blocs of Democratic- and Republican-appointed Justices that has existed since the beginning of the Court's 2010 Term, a division that stands in sharp contrast with earlier periods in the Court's history. Another indication of the distinctiveness of the current era is the number of important decisions in which the Justices lined up along party lines. As noted earlier, between 1790 and early 2010 there were only two decisions that the Guide to the U.S. Supreme Court designated as important and that had at least two dissenting votes in which the Justices divided along party lines, about one-half of one percent. ${ }^{61}$ By contrast, among the cases decided by the Court in the 2010-14 Terms, seven decisions in which the Court divided 5-4 or (in one case) 5-3 along party lines are obvious candidates for inclusion in the Guide's

${ }^{58}$ We will return to the period from 1969 to 1990 in Part IV to examine more closely the differences between the Court of that period and the current Court.

${ }^{59}$ Savage, Guide to the U.S. Supreme Court at 1294-1340 (cited in note 36). Savage's list of important cases terminates in the mid-2009 Term.

${ }^{60}$ That case was Fed. Election Commission v National Conservative Political Action Comm., 470 US 480 (1985). Four Justices (two Democrats and two Republicans) wrote or joined dissenting opinions. Of those four, the Court's two Democrats (Byron White and Thurgood Marshall) dissented most fully from the Court's decision, and David G. Savage treats the Court's vote as 7-2. Savage, Guide to the U.S. Supreme Court at 1240 (cited in note 36).

${ }^{61}$ In that period, there were 397 important decisions on which there were at least two dissents. The Guide's list of important decisions includes only part of the Court's 2009 Term. 
list of important decisions. ${ }^{62}$ During the Court's 2015 Term, the Justices split 4-4-most likely on partisan lines-in high-visibility cases on public sector unions and on President Obama's immigration directive. ${ }^{63}$

\section{PARTISANSHIP AND IDEOLOGICAL CONFORMITY}

Today's partisan divide manifests itself in other ways. Most striking, the groups of Justices appointed by Republican presidents and by Democratic presidents have each become more ideologically homogeneous. Moreover, each of the distinct groups of Justices lacks centrists, with the partial exception of Justice Kennedy. Instead, there is ideological conformity within each group, even as the groups have diverged over time.

The high level of homogeneity among Democratic- and among Republican-appointed Justices can be measured by the standard de-

${ }^{62}$ Those decisions are: Burvell v Hobby Lobby Stores, 134 S Ct 2751 (2014) (interpreting the Religious Freedom Restoration Act to protect closely held corporations from a mandate to include certain contraceptives in employee health plans); McCutcheon v FEC, 134 S Ct 1434 (2014) (striking down a federal statutory provision that put limit on an individual's total contributions to election candidates and candidate committees); Shelby Cnty v Holder, $133 \mathrm{~S}$ Ct 2612 (2013) (striking down Title IV of the Voting Rights Act); Florence v Bd of Chosen Freebolders, 132 S Ct 1510 (2012) (allowing routine strip-searches of arrestees at jails); AT\& T Mobility LLC v Concepcion, 563 US 333 (2011) (disallowing state restrictions on contract provisions prohibiting class actions in arbitration); Arizona Free Enterprise Chub's Freedom Chu $P A C v$ Bemett, 131 S Ct 2806 (2011) (striking down a state system of public funding for candidates for state offices); and Chamber of Commerce v Whiting, 131 S Ct 1968 (2011) (allowing sanctions on employers for hiring of undocumented aliens). In preparing this inventory of cases, we consulted with David Savage, author of the Guide.

${ }^{63}$ Those cases are Friedrichs v California Teachers Association, 136 S Ct 1083 (2016) (dividing 4-4 on whether mandatory fees to public sector unions violate free speech rights), and United States v Texas, $136 \mathrm{~S} \mathrm{Ct} 2271$ (2016) (dividing 4-4 on legality of 2014 Obama immigration directive). For news stories speculating that these 4-4 splits were a Democratic-Republican split, see Adam Liptak, Victory for Unions as Supreme Court, Scalia Gone, Ties 4-4, NY Times (March 29, 2016), available at http://www.nytimes.com/2016/03/30/us/politics/friedrichs-v -california-teachers-association-union-fees-supreme-court-ruling.huml?_r $=0$; Robert Barnes, Supreme Court Won't Revive Obama Plan to Shield Illegal Immigrants from Deportation, Wash Post (June 23, 2016), available at https://www.washingtonpost.com/politics/supreme-court-wont -revive-obama-plan-to-shield-illegal-immigrants-from-deportation/2016/06/23/6cea5fle-3950 -11 e6-9ced-d6005beac8b3_story.html. In other high-profile cases (involving a religious liberty challenge to the Affordable Care Act and Article III standing limits on class action lawsuits), the Justices may well have masked partisan divisions by issuing ambiguous, inconclusive opinions. See Mark Joseph Stern, SCOTUS Misses an Opportunity to Gut Class Actions and Consumer Privacy Lawss, Slate (May 16, 2016), available at http://www.slate.com/blogs/the_slatest /2016/05/16/spokeo_v robins spares class_actions and consumer_privacy.html; Garrett Epps, The U.S. Supreme Court's Nonsense Ruling in Zubik, The Atlantic (May 16, 2016), available at http://www.theatlantic.com/politics/archive/2016/05/the-supreme-courts-non-sensical-rul ing-in-zubik/482967/. 
viations of the Justices' conservative votes within each group,${ }^{64}$ based on the coding of votes in the Supreme Court Database. The lower the standard deviation, the greater the ideological conformity within each group. The results are shown in figure 1, divided into subperiods that track changes in the Court's composition.

For the Court's Democratic-appointed Justices, the standard deviation was very high in the 1986-93 period because the only Democratic appointees in that period were the very liberal Thurgood Marshall and the moderate conservative Byron White. ${ }^{65}$ In the longer period from 1994 through 2008, the two Democratic-appointed Justices were the like-minded Ruth Bader Ginsburg and Stephen Breyer, and the standard deviations were low. That remained true after Ginsburg and Breyer were joined by Sonia Sotomayor and Elena Kagan.

The change came later for the Court's Republican-appointed Justices. The standard deviation remained high as long as the relatively liberal John Paul Stevens and David Souter remained on the Court. After Souter retired at the end of the 2008 Term, though, the standard deviation fell by almost half; when Stevens retired after the 2009 Term, it again fell by half. ${ }^{66}$ With a more homogeneous set of Republican-appointed Justices on the Court, the standard deviation has remained low ever since.

Similarly, as figure 2 shows, the Republican and Democratic appointees have separated from each other ideologically. The average difference between these two sets of Justices in the frequency with which they cast conservative votes has fluctuated considerably over time, but there was a general movement upward in the early $1990 \mathrm{~s}$ and again in 2009 and 2010, as the Court's Republican and Democratic appointees became more ideologically distinct from each other. As in other analyses that we present, the percentages of conservative and liberal votes cast by a Justice or by a set of Justices can be

\footnotetext{
${ }^{64}$ The standard deviation measures how widely a range of scores deviates from the mean of those scores. For the formula, see, e.g., Hubert M. Blalock, Jr., Social Statistics 67 (McGrawHill, 1960). The standard deviation is useful for our purposes because it indicates the extent to which the Justices of one party vary in their ideological positions.

${ }_{6.5}$ There were no standard deviations for the 1991-93 Terms because there was only one Democrat on the Court; Marshall retired before the 1991 Term and White before the 1993 Term.

${ }^{66}$ When Stevens retired, it fell from 16.2 to 9.1 percent; when Souter retired, it fell to 4 percent.
} 


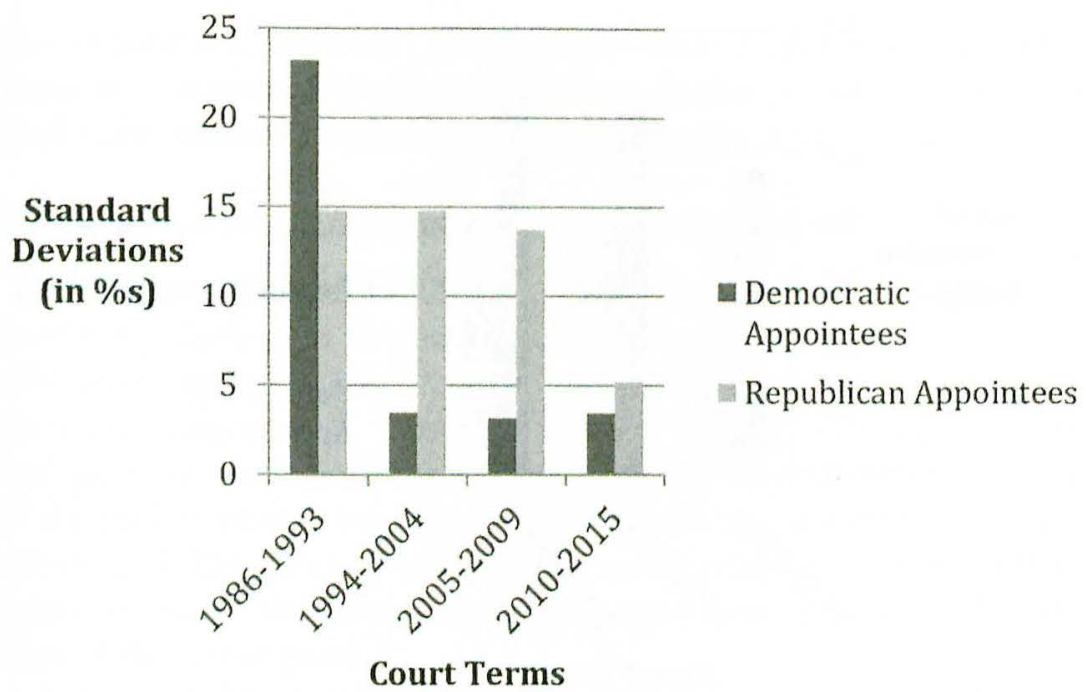

Figure 1. Mean standard deviations of percentages of conservative votes among Justices appointed by presidents from each party. The standard deviations shown for each period are the means of the standard deviations for individual Court terms during that period. The proportions of conservative votes are calculated from data in the Supreme Court Database, with votes that are not defined as either liberal or conservative excluded.

compared over time only with considerable caution, because those percentages are affected by the composition of the cases that the Court decides at any given time. For this reason, the data in figure 2 do not necessarily mean that Democratic-appointed Justices became slightly more conservative and Republican-appointed Justices became substantially more conservative across the periods shown. ${ }^{67}$

Does the growing ideological distance between these two groups of Justices mean that moderate Justices have disappeared from the Court? That question cannot be answered definitively, because there is no clear benchmark for moderation. ${ }^{68}$ But it appears that Republican-

\footnotetext{
${ }^{67}$ Thus when the Court's membership is unchanged, term-by-term fluctuations in percentages of liberal and conservative decisions are likely to result primarily from changes in the composition of the Court's agenda. Fluctuations in the agenda have an even greater impact on the ideological direction of the small numbers of decisions in a given term that receive the greatest attention.

${ }^{68}$ For a recent academic treatment of this subject (measuring moderation by the number of swing Justices there are on the Court), see Brandon Bartels, The Sources and Consequences of Polarization in the U.S. Supreme Court, in James Thurber and Antoine Yoshinaka, eds, American Gridlock 171-200 (Cambridge, 2015).
} 


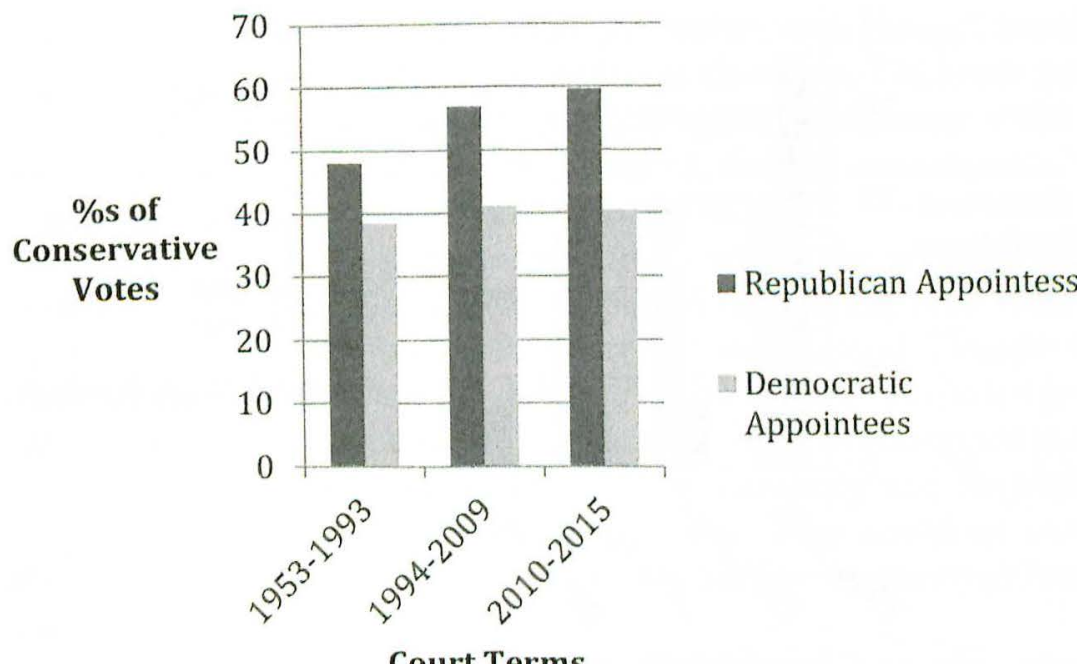

Figure 2. Mean percentage of conservative votes among Justices appointed by presidents from each party. As in figure 1, the proportions of conservative votes are calculated from data in the Supreme Court Database, with votes that are not defined as either liberal or conservative excluded. The percentages shown are the means of the mean percentages of conservative votes among a party group (for instance, all Democratic appointees). The periods coincide with the retirement of the last Democratic moderate (Byron White) in 1993 and last Republican moderate (John Paul Stevens) in 2010 .

appointed Justices are more strongly conservative than the Court's Democratic-appointed Justices are liberal. ${ }^{69}$ There are no strong liberals on today's Court; more telling, analyses by Lee Epstein, William Landes, and Richard Posner rank four Roberts Court Republican-appointed Justices as among the most conservative Justices ever to sit on the Court. ${ }^{70}$ Finally, the evidence indicates that

\footnotetext{
${ }^{69}$ See Strauss, 21 Democracy at 114 (cited in note 15) (arguing that there are no strong liberals on today's Court); Lee Epstein, William M. Landes, and Richard A. Posner, The Bebavior of Federal fudges: A Theoretical and Empirical Study of Rational Choice 108-09 (Harvard, 2013) (contending that today's Republican appointees are among the most conservative Justices ever to sit on Court).

${ }^{70}$ See id at table 3.2 (ranking - based on percentage of conservative votes cast-Roberts, Thomas, Alito, Scalia as among ten most conservative since 1937); Lee Epstein, William M. Landes, and Richard A. Posner, Revisiting the Ideology Ranking of Supreme Court fustices, 44 J Legal Stud S295, 313-14 (Thomas, Scalia, Alito among most conservative with respect to votes cast in cases covered by New York Times and Roberts among most conservative in cases decided 5-4). See also notes $142-52$ and accompanying text (discussing Democratic appointments strategies).
} 
the separation between Democratic- and Republican-appointed Justices is unique in the Court's history. In the parts that follow, we probe the reasons for this fundamental change in the Court.

\section{Partisan Polarization in American Politics}

Starting in the 1980s, there has been a substantial increase in partisan polarization in government and among political elites outside government. ${ }^{71}$ As noted earlier, we focus on two overlapping forms of polarization. Through partisan sorting, ideological views and partisan identifications are more closely related than they were in the mid-twentieth century. ${ }^{72}$ Through affective polarization, Democrats and Republicans increasingly see themselves as members of opposing teams and increasingly hold negative attitudes toward members of the other party. ${ }^{73}$

It is inevitable that the growth in political polarization in both of these senses would affect the Supreme Court, both directly and indirectly. In the first section of this part, we highlight the growth of polarization in government. In the second section we examine polarization in the larger elite world, including media outlets, the legal profession, and the academy.

\section{A. GOVERNMENT}

The growing ideological separation between the two parties is reflected in the federal government. Democratic and Republican

\footnotetext{
${ }^{71}$ For general treatment of the rise of polarization in Congress, among elites, and among media outlets, see Nolan M. McCarty, Keith T. Poole, and Howard Rosenthal, Polarized America: The Dance of Ideology and Unequal Riches (MIT, 2006); Cass R. Sunstein, Republic.com 2.0 (Princeton, 2009); Earl Black and Merle Black, Divided America: The Ferocious Powver Struggle in American Politics (Simon \& Schuster, 2008); Sean M. Theriault, Party Polarization in Congress (Cambridge, 2008); Mark A. Graber, The Coming Constitutional Yo-Yo? Elite Opinion, Polarization, and the Direction of Judicial Decision Making, 56 Howard L J 661, 681703 (2013); Geoffrey C. Layman et al, Party Polarization in American Politics, 8 Ann Rev Pol Sci 83 (2006).

In contrast with people in government and other political elites, the extent to which polarization has grown in the mass public is uncertain and a matter of debate. However, there is evidence of an increased level of affective polarization in the public as a whole. See Shanto Iyengar and Sean J. Westwood, Fear and Loathing Across Party Lines: New Evidence on Group Polarization, 59 Am J Pol Sci 690 (2015); Miller and Conover, 68 Pol Res $Q$ at 225 (cited in note 8).

${ }^{72}$ See notes 74-82 and accompanying text.

${ }^{73}$ See notes $107-09$ and accompanying text.
} 
officials have grown more distinct from each other ideologically and more hostile to each other.

Because congressional behavior can be analyzed through voting patterns, the separation between the parties is especially clear in Congress. ${ }^{74}$ Today, Republicans and Democrats in Congress are ideologically distinct, as measured by their votes. No Democrat in either the House or the Senate is more conservative than the most liberal Republican in the same chamber. ${ }^{75}$ By 2009 , the ideological distance between the Democratic and Republican parties was greater than it had been at any time since Reconstruction. ${ }^{76}$ This trend is largely attributable to the rightward movement of the Republican Party. ${ }^{77}$ By 2012, the growth of the Tea Party had pushed the divide even further (as relatively moderate senators such as Texas's Kay Bailey Hutchinson were replaced by strong conservatives like Ted Cruz). ${ }^{78}$ In contrast, while the Democratic Party has become more liberal over time, the change has been less dramatic. ${ }^{79}$ The dearth of members who can be characterized as moderates is one of the most striking features of today's Congress. ${ }^{80}$ In 1980, moderates made up approximately 40 percent of Congress; today, moderates are nearly extinct, making up less than 5 percent of Congress. ${ }^{81}$

\footnotetext{
${ }^{74}$ On ramifications of partisanship in Congress, see Neal Devins, Party Polarization and Congressional Committee Consideration of Constitutional Questions, 105 Nw U L Rev 737, 75359, 776-81 (2011). For related discussion of polarization's impact on state politics, see Neal Devins and Saikrishna Prakash, 50 States, 50 Attomeys General, 50 Approaches to the Duty to Defend, 124 Yale L J 2100, 2150-54 (2015).

${ }^{75}$ Data on the ideological ordering of senators and House members are presented at $D W$ NOMINATE Scores 1st to 113th Congresses, Voteview.com, voteview.com/dwnl.htm.

${ }^{76}$ See Party Polarization: 1879-2014, at http://voteview.com/political_polarization_2014 .htm. The widened ideological gap between Republicans and Democrats in Congress reflects multiple forces, including growing differences in the personal ideological positions of congressional Republicans and Democrats, increasingly extreme views of party activists who influence members' positions, and members' and leaders' interest in enhancing their party's power in government and in the country. For a discussion of how party efforts to amass power exacerbate polarization and produce more party-line voting, see Theriault, Party Polarization in Congress 177-80 (cited in note 71).

${ }^{77}$ See Matt Grossman and David A. Hopkins, Asymmetric Politics 253 (Oxford, 2016).

${ }^{78}$ See "Common Space" DW-NOMINATE Scores with Bootstrapped Standard Errors (7oint House and Senate Scaling), at http://voteview.com/dwnomin_joint_house_and_senate.htm.

${ }^{79}$ Grossman and Hopkins, Asymmetric Politics at 253 (cited in note 77).

${ }^{*}$ See Richard L. Hasen, End of the Dialogue? Political Polarization, the Supreme Court, and Congress, 86 USC L Rev 205, 235-37 (2013).

${ }^{81}$ See The Polarization of the Congressional Parties, at http://voteview.com/political_polar ization_2014.hum.
} 
The ideological distance between the parties today presents a striking contrast to the Congresses of the Warren and Burger Court eras (1953-86). The rapid rise in partisan sorting began in the 1980s; starting in the 1990s, a surge of southern Republicans substantially propelled the polarization of the parties. ${ }^{82}$

These developments are illustrated in figure 3. The figure, developed by Keith Poole and Howard Rosenthal, employs a measure of the ideological positions of members of Congress to show the ideological distance between the two parties in the House and Senate over time..$^{83}$ The figure highlights the sharp increase in polarization that has occurred in recent decades. In contrast with the late nineteenth and early twentieth centuries, Congress from the 1920s to the 1970s featured relatively limited polarization between the parties. But that period was followed by a sharp increase, resulting in a Congress that is even more polarized now than the Congress of a century ago.

One area in which polarization in Congress and the executive branch has had a particularly powerful effect is in the process of nominating and confirming federal judges. As we will discuss in Part III, in recent decades presidents - especially Republican presidents-have increasingly chosen nominees who represent their party's ideological orientation. In the Senate, there has been a dramatic increase in the amount of time it takes to confirm lower-court judges and an equally dramatic decrease in the percentage of lower-court nominees whom the Judiciary Committee now approves. ${ }^{84}$ Over the past two decades, and especially over the past ten years, the number of failed nominations has sharply increased and failed nominations for the courts of appeals typically lingered in the Senate for over a year. ${ }^{85}$ It was this trend that spurred Senate Democrats in 2013 to invoke the so-called "nuclear option"- allowing for a simple up-or-down majority vote on presi-

\footnotetext{
${ }^{82}$ See Earl Black and Merle Black, The Rise of Soutbern Republicans (Harvard, 2003).

${ }^{83}$ Chart available at http://voteview.com/political_polarization_2014.htm.

${ }^{84}$ See Sarah A. Binder and Forrest Maltzman, The Politics of Advice and Consent: Putting Fudges on the Federal Bench, in Lawrence C. Dodd and Bruce I. Oppenheimer, eds, Congress Reconsidered 265 (10th ed 2012); Roger H. Davidson and Walter J. Oleszek, Congress and Its Members 379-87 (CQ Press, 11th ed 2008).
}

${ }^{85}$ See Binder and Maltzman, Congress Reconsidered at 266-71 (cited in note 84). 


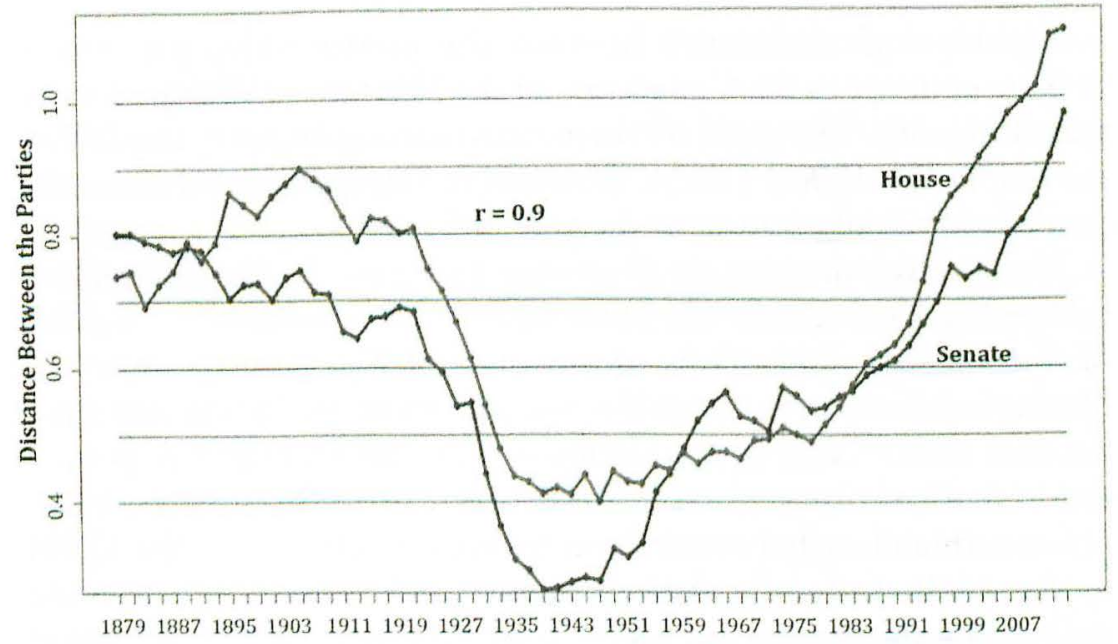

Figure 3. Party polarization, 1879-2014. Distance between the parties on the first (liberalconservative) dimension. Source: Keith T. Poole and Howard Rosenthal, voteview blog.

dential nominations to lower courts, independent agencies, and executive branch positions. ${ }^{86}$

Senate voting on judicial nominees, especially Supreme Court nominees, has also become increasingly partisan. ${ }^{87}$ Except for Clarence Thomas, the Justices on the Court today who were nominated prior to 2005 were all confirmed by unanimous or overwhelmingly positive votes. ${ }^{88}$ Starting with John Roberts, however, nominees have received large numbers of negative votes from senators of the opposing party. ${ }^{89}$

${ }^{86}$ See Humberto Sanchez, A Landmark Change to the Filibuster, CQ Weekly Rpt, 1992 (Dec 2, 2013). For tables detailing a dramatic rise in filibusters tied to judicial and other executive branch nominations, see US Senate, Senate Action on Cloture Motions, archived at https://perma.cc /NR5X-4HW4; Sahi Kapur, Charts: Why the Filibuster May Soon Be Dead, Talking Points Memo (Nov 25, 2013, 6:00 a.m.), archived at https://perma.cc/WBR3-QM9K.

${ }^{87}$ See A. E. Dick Howard, The Changing Face of the Supreme Court, 101 Va L Rev 231, 292315 (2015).

${ }^{88}$ Thomas was confirmed by a 52-48 vote. Stephen Breyer received nine negative votes, Ruth Bader Ginsburg three; Antonin Scalia and Anthony Kennedy were confirmed unanimously. See U. S. Senate, Supreme Court Nominations, Present-1789, archived at https:// perma.cc/EV9N-GPZG.

"' Consider, for example, then-Senator Barack Obama's statement (in explaining his no vote on Chief Justice Roberts) that he has "absolutely no doubt" that Roberts was qualified to sit on the Court but that he gave weight to the impact of a Justice's "deepest values" and "the depth and breadth" of a Justice's "empathy." See Nomination of John Roberts, 151 Cong Rec 21032 (cited in note 21). 
Roberts, Samuel Alito, and Sonia Sotomayor all had the unanimous support of the president's party in Congress, and only one Democrat voted against Elena Kagan. Democrats split evenly in the Roberts confirmation vote; Alito, Sotomayor, Kagan, and Gorsuch were opposed by a majority of members of the opposition party. ${ }^{90}$ It is difficult to imagine that a nominee like Ruth Bader Ginsburg could be confirmed today with only three negative votes, or that a nominee like Antonin Scalia could win unanimous approval; indeed, the extraordinary decision of Senate Republicans to block any consideration of President Obama's nomination of Merrick Garland to succeed Justice Scalia underscores how divisive and partisan Supreme Court confirmation battles have become. ${ }^{91}$

\section{B. THE LARGER ELITE WORLD}

Party polarization in government tracks a growing ideological divide among affluent, well-educated Democrats and Republicans. During the 1960s and 1970s, when both Republicans and Democrats occupied every ideological niche, Democratic and Republican elites tended to agree on some major issues, especially with respect to civil rights and civil liberties. ${ }^{92}$ Today, however, Democratic and Republican elites are at opposite ends of the ideological spectrum in their policy positions. Indeed, Democratic elites are more liberal than other Democrats, and Republican elites are more conservative than other Republicans. $^{93}$

The consequences of such elite polarization are profound. Although the potential impact of the views of the general public on the

\footnotetext{
${ }^{90}$ Hasen, 86 USC L Rev at 246-48 (cited in note 80). For this very reason, there is now widespread speculation that the Senate (if controlled by the opposition party) would not allow a vote on future Supreme Court nominations. See Linda Hirschman, Why the Next Supreme Court Vacancy Will Favor Liberals No Matter Who Retires, Wash Post (Dec 31, 2015), archived at https://perma.cc/G9DJ-L3AW.

${ }^{91}$ See Shear and Steinhauer, More Republicans (cited in note 3). See also Brent Martin, Cbief Fustice Roberts: Scalia, Ginsburg Wouldn't be Confirmed Today, Nebraska Radio Network (Sept 19, 2014), archived at https://perma.cc/RQ6Z-MRT4 (quoting Chief Justice Roberts 2014 comment that neither Ginsburg nor Scalia "would have a chance" of confirmation today).

${ }^{92}$ See Herbert McClosky, Consensus and Ideology in American Politics, 58 Am Pol Sci Rev 361 (1964); Peter Skerry, The Class Conflict over Abortion, 52 Pub Interest 69 (1978).

${ }^{03}$ See Graber, 56 Howard L J at 693-712 (cited in note 71) (discussing polling data); Geoffrey C. Layman and Thomas M. Carsey, Party Polarization and "Conflict Extension" in the American Electorate, $46 \mathrm{Am} \mathrm{J} \mathrm{Pol} \mathrm{Sci} \mathrm{786,} 789$ (2002) (noting elite polarization with respect to "social welfare, racial, and cultural issues").
} 
Supreme Court receives a great deal of attention, ${ }^{94}$ elite values exert an even more powerful impact. Because the Justices are part of the elite sector of society, their own views tend to reflect elite attitudes. ${ }^{95}$ During the 1960s, for example, Warren Court liberalism was fueled by elite support in both parties; today, the Roberts Court's sharp ideological divide is fueled by the partisan divide between elite Democrats and Republicans. ${ }^{96}$

During the Warren and Burger Court eras, Supreme Court decisions on race, religion, and other socially divisive issues tended to track elite views. ${ }^{97}$ The Court's school prayer decisions of 1962 and 1963 , for example, were widely unpopular with the mass public (85 percent disapproved in a 1964 survey), but elite support "for the Supreme Court's secularization project was clearly visible in the activities of law professors and deans [and] in the prominent newspaper editorials endorsing" the Court's decisions. ${ }^{98}$ On issues involving free speech and equal protection, several studies pointed to a gap between elite and popular opinion. As one study concluded, "[s]ocial learning, insofar as it affects support for civil liberties, is likely to be greater among the influentials (that, is political elites) of the society than among the mass public." ${ }^{\prime 99}$ Likewise, attitudes toward abortion in 1965-80 revealed a striking gap between elites and the mass public; indeed, "the best predictor of abortion attitudes" was level of education. ${ }^{100}$

Unlike elites during the Warren and Burger Court eras, today's elites, like Congress itself, are sharply divided along partisan lines.

${ }^{14}$ See, for example, Barry Friedman, The Will of the People: How Public Opinion Has Influenced the Supreme Court and Shaped the Meaning of the Constitution (Macmillan, 2009); and Richard L. Pildes, Is the Supreme Court a "Majoritarian" Institution?, 2010 Supreme Court Review 103.

${ }^{95}$ Baum and Devins, 98 Georgetown L J at 1537-46 (cited in note 12).

${ }^{96}$ We are not the first to make this point. See Graber, 56 Howard L J at 665 (cited in note 71).

${ }^{97}$ Baum and Devins, 98 Georgetown L J at 1570-74 (cited in note 12) (documenting that Supreme Court is more likely to adhere to views of individuals with postgraduate degrees than individuals with lower levels of education).

${ }^{98}$ John C. Jeffries, Jr. and James E. Ryan, A Political History of the Establishment Clause, 100 Mich L Rev 279, 325 (2001). For 1964 survey data, see Univ of Mich Survey Research Ctr, American National Election Studies: 1964 Pre-Post Election Study 13 (Sept-Nov 1964), archived at https://perma.cc/PDV8-Q8NR. The decisions were Engelv Vitale, 370 US 421 (1962); and Abington School District v Schempp, 374 US 203 (1963).

${ }^{90}$ Herbert McClosky and Alida Brill, Dimensions of Tolerance: What Americans Believe About Civil Liberties 233 (Russell Sage, 1983). See also McClosky, 58 Am Pol Sci Rev at 373 (cited in note 92) (noting that "political influentials" give "stronger approval" to "democratic ideas" than "ordinary voters"). For additional studies, see sources cited in Graber, 56 Howard L J at 686-87 (cited in note 71).

${ }^{100}$ Donald Granberg and Beth Wellman Granberg, Abortion Attitudes, 1965-1980: Trends and Determinants, 12 Family Planning Persp 250, 254 (1980). 
Polling data make it clear that the opinions of Republicans and Democrats with high socioeconomic status and high levels of education diverge more than the opinions of the population as a whole. In turn, the political class is dominated by polarized elites and, as such, the "extremes are overrepresented in the political arena and the center underrepresented." 101

This state of affairs is evident in 2005, 2011, and 2014 surveys by the Pew Research Group. ${ }^{102}$ By correlating income and education to political beliefs, the Pew studies make clear that the most liberal Americans are affluent, well-educated Democrats and the most conservative Americans are affluent, well-educated Republicans. ${ }^{103}$ These studies also highlight growing polarization among elites. Most significant (and tracking the hardening of the right on today's Supreme Court) ${ }^{104}$ these studies identify dramatic changes among strong political conservatives since the 1980s. In the 1980s, conservatives divided between two groups: economic and social conservatives. By 2005, economic conservatives had adopted the cultural beliefs of social conservatives. ${ }^{105}$ Liberal Democrats became even more liberal during this period. On same-sex marriage, abortion rights, and restrictions on civil liberties tied to the War on Terror, "[m]embers of the most affluent well educated group of Democrats tended to be far more liberal on all issues than members of other Democratic groups." 106

At the same time, political competition has become more personalized and more bitter. Republicans and Democrats increasingly view each other negatively, see themselves in competition, and are "angry" when the other side wins a close election. ${ }^{107}$ Moreover, voters now seek out information to back up preexisting policy preferences

\footnotetext{
${ }^{101}$ Morris P. Fiorina et al, Culture War? The Myth of a Polarized America 200 (Longman, $3 \mathrm{~d}$ ed 2011).

${ }^{102}$ The 2005 Political Typology, Pew Research Center for the People and the Press (May 10, 2005), archived at https://perma.cc/SN5Z-8XU9; Beyond Red vs. Bhue: Political Typology, Pew Research Center for the People and the Press (May 4, 2011), at http://www.people-press.org /files/legacy-pdf/Beyond-Red-vs-Blue-The-Political-Typology.pdf; Beyond Red vs. Bhue: The Political Typology, Pew Research Center (June 26, 2014). The 2005 and 2011 polls are discussed in Graber, 56 Howard L J at 695-700 (cited in note 71).

${ }^{103}$ Pew, 2005 Political Topology at 64-65 (cited in note 102); Pew, Beyond Red v. Blue (2011) at 105, 109, 111 (cited in note 102); Pew, Beyond Red v. Blue (2014) at 92, 99-102, 111-12 (cited in note 102).

${ }^{104}$ See Part IV.

${ }^{105}$ Pew, 2005 Political Topology at 53 (cited in note 102).

${ }^{106}$ Graber, 56 Howard L J at 698 (cited in note 71).

107 See Miller and Conover, 68 Pol Res Q at 232 (cited in note 8).
} 
rather than to educate themselves. ${ }^{108}$ The level of animosity along ideological lines is suggested by a 2014 survey that found that 23 percent of people with consistently liberal views would be unhappy if an immediate family member were to marry a Republican, and 30 percent of their conservative counterparts would be unhappy about a marriage to a Democrat. ${ }^{109}$

The growth in ideological and partisan polarization is reflected in today's news media. During the Warren and Burger Court eras, moderate-to-liberal network television and daily newspapers dominated public discourse. ${ }^{10}$ As a response to a perceived liberal bias in the media, conservatives established their own informational infrastructure, which culminated with the establishment of the Fox News channel. ${ }^{111}$ Liberal ideologues attempted to replicate this trend, though they were not as successful. ${ }^{12}$ Over the past thirty years, the proliferation of cable television, the Internet, and the blogosphere has transformed the public discourse by producing major media outlets that are distinctly on the political left or right. ${ }^{13}$ Surveys show that among people who are politically involved, liberals and conservatives have strong tendencies to select news sources whose political orientation is similar to their own. ${ }^{114}$

${ }^{108}$ See Ilya Somin, Knowledge About Ignorance: New Directions in the Study of Political Information, 18 Critical Rev 255, 260-62 (2006); Neal Devins, The D'Ob! of Popular Constitutionalism, 105 Mich L Rev 1333, 1340-46 (2007).

${ }^{109}$ Political Polarization in the American Public 48, Pew Research Center (June 12, 2014).

${ }^{110}$ See William Powers, The Massless Media, Atlantic (Jan/Feb 2005) at 124 ("[T]he political culture of the 1940s and 1950s discouraged extremism.... Politics hewed to the center, and the media both reflected and reinforced this tendency.... Th[e] establishment consensus exploded in the 1960s and 1970s, ... but the mass media hung on for a few decades, a vestigial reminder of what had been."). For additional discussion, see notes 92-100 and accompanying text (examining how elite social networks favored liberal outcomes during 1969-90 era).

${ }^{111}$ Grossman and Hopkins, Asymmetric Politics at 147 (cited in note 77).

112 Id at $152-53$.

113 See Richard A. Posner, Bad News, NY Times (July 31, G9 2005) ("The current tendency to political polarization in news reporting is thus a consequence of changes not in underlying political opinions, but in costs, specifically the falling cost of new entrants."). Polarization was also fueled by changes in federal regulatory policy, most notably the repeal of the Fairness Doctrine in 1987, and the related proliferation of conservative and liberal media outlets that allowed consumers to get their news and opinion programming from stations that reinforced preexisting ideological commitments. See Cass R. Sunstein, Deliberative Trouble? Why Groups Go to Extremes, 110 Yale L J 71, 101 (2000) (arguing that changes in the news media resulting from the repeal of Fairness "may create group polarization" as "all too many people might be exposed to louder echoes of their own voices").

${ }^{114}$ Markus Prior, Medial and Political Polarization, 16 Ann Rev Pol Sci 101 (2013); Amy Mitchell et al, Political Polarization and Media Habits, Pew Research Center (Oct 21, 2014), at 
Analogous changes have occurred in the legal profession. In the 1960s and 1970s the elite segment of the legal profession, including bar groups like the American Bar Association, leaned to the left. ${ }^{115}$ In response, conservatives in the profession sought to redress what they saw as an ideological imbalance. ${ }^{116}$ One result was the establishment of public interest law firms representing conservative positions. ${ }^{117}$ Another was the creation and growth of the Federalist Society, which originated as a reaction to the perceived liberal bias of elite law schools. ${ }^{118}$ The Federalist Society serves as a reference group for conservative law students and lawyers, each with its own organizations and activities under the society's umbrella; ${ }^{119}$ the American Constitution Society, created in response to the success of the Federalist Society, serves a similar though less critical function for liberals. ${ }^{120}$

These developments are reflected in the emergence of distinct career paths for conservatives and liberals in the elite segment of

http://www.journalism.org/2014/10/21/political-polarization-media-habits/. Due to this trend, conservative Republicans have become increasingly ideologically distinct from Democrats. See Grossman and Hopkins, Asymmetric Politics at 157 (cited in note 77).

${ }^{115}$ See Teles, Conservative Legal Movement at 41-59 (cited in note 13) (tracking rise of liberal legal establishment). Changes in the views of the elite segment of the legal profession were reflected in the shift of the American Bar Association from its traditional conservatism to a more liberal stance beginning in the 1960s. Id at 28-35. There was a similar leaning to the left in the news media that covered the Supreme Court. The most prominent Supreme Court reporters, such as Anthony Lewis and Linda Greenhouse of the New York Times and Nina Totenberg of National Public Radio, reported and assessed the Justices' positions primarily from a liberal perspective. Conservative complaints about the impact of a liberal elite sometimes singled out Greenhouse, and Thomas Sowell and Laurence Silberman popularized the term "Greenhouse effect" to refer to this impact. See Thomas Sowell, Blackmun Plays to the Crowd, St. Louis Post-Dispatch 7B (May 4, 1994); Attacking Activism, 7udge Names Names, Legal Times 14-17 (June 22, 1992) (hereafter Attacking Activism) (reporting on speech by federal court of appeals Judge Laurence Silberman).

${ }^{116}$ See generally, Ann Southworth, Lawvers of the Right: Professionalizing the Conservative Coalition (Chicago, 2008); Teles, Conservative Legal Movement at 58-59, 135-80 (cited in note 13). For a discussion of the efforts of the Reagan administration to transform the legal profession by credentialing young conservative lawyers, see notes 170-76 and accompanying text (discussing Reagan administration efforts to groom conservatives who would later become federal court judges and Supreme Court Justices).

${ }^{117}$ See Southworth, Lawyers of the Right at 8-40 (cited in note 116).

${ }^{118}$ Michael Avery and Danielle McLaughlin, The Federalist Society: How Conservatives Took the Law Back from Liberals (Vanderbilt, 2013); Hollis-Brusky, Ideas with Consequences (cited in note 13).

${ }^{119}$ Hollis-Brusky, Ideas with Consequences at 13-15 (cited in note 13); descriptions of the sectors of the society for students and for practicing lawyers are at its website, http://www .fed-soc.org/.

${ }^{120}$ See Hollis-Brusky, Ideas with Consequences at 166-67 (cited in note 13). 
the legal profession. Outstanding students at the most prestigious law schools increasingly move into clerkships with federal appellate judges who share their ideological orientations, and then into presidential administrations, law firms, and other institutions that also share their liberal or conservative views. ${ }^{121}$

Of course, Supreme Court Justices are part of the social and legal elite. They are "overwhelmingly upper-middle or upper-class and extremely well educated, usually at the nation's more elite universities." 122 The current Justices of the Supreme Court, as Judge Richard Posner has observed, are "sheltered, cosseted," and most of them "grew up in privileged circumstances and do not rub shoulders with hoi polloi." ${ }^{23}$ All the Justices who sat on the Court from 2010 through 2016 attended Harvard or Yale law schools, nearly all came from wellto-do families, and those who did not (Thomas, Sotomayor) received million dollar plus advances for writing their autobiographies. ${ }^{124}$ In Part IV, we explain the importance of elite social networks to Supreme Court decision making and to the growth in partisan polarization on the Court.

\section{Explaining the Growth in Polarization: The Appointment Process}

As we have suggested, the simultaneous growth of polarization on the Supreme Court and among elites in politics, the media, and the legal profession is not a coincidence; changes in the Court

\footnotetext{
${ }^{121}$ See William E. Nelson et al, The Liberal Tradition of the Supreme Court Clerkship: Its Rise, Fall, and Reincarnation?, 62 Vand L Rev 1749, 1775-91 (2009) (discussing both postclerk employment and the increasing polarization among Justices in selecting clerks who had previously worked for appeals court judges of the same political party). For additional discussion, see notes 258-61 and accompanying text.

${ }^{122}$ Michael J. Klarman, What's So Great About Constitutionalism, 93 Nw U L Rev 145, 189 (1998).

${ }^{123}$ Richard A. Posner, How Fudges Think 306 (Harvard, 2008).

${ }^{124} \mathrm{Id}$; Howard, 101 Va L Rev at 251-52 (cited in note 87); Adam Liptak, Sotomayor Got $\$ 1.175$ Million for Memoir, Forms Reveal, NY Times (May 27, 2011), archived at https:// perma.ce/5EAE-SYWJ; Brent Kendall, Sotomayor Got \$1.175 Million Book Advance, Wall St J (May 27, 2011 3:28 p.m.), archived at https://perma.cc/QF8Z-R2DH. When campaigning for president, Donald Trump issued a list of twenty-one potential Supreme Court nominees that seemed "a revolt against the elites." Adam Liptak, Trump's Supreme Court List: Ivy League? Out. The Heartland? In, NY Times (Nov 14, 2016), available at http://www.nytimes .com/2016/11/15/us/politics/trump-supreme-court-Justices.html?_r $=0$. Trump's list largely eschewed elites from the east or west coast as well as candidates who attended Harvard or Yale law schools. Id.
} 
reflect changes in its political environment. In this part and in Part IV we probe the linkages between the two. In this part, we examine changes in the process of presidential appointment of Justices. In Part IV we examine changes in the social environments of the Justices.

The role of ideology in the appointment of Justices has grown in both Democratic and Republican administrations over the past few decades. But this growth has taken different forms in the two parties, and it has been more substantial on the Republican side due to the fact that Republicans have become more ideologically homogenous than Democrats. ${ }^{125}$

\section{A. DEMOCRATIC PRESIDENTS}

In nominating Supreme Court Justices, presidents consider much more than the "objective" qualifications of potential nominees, such as their legal abilities and their ethical behavior. Presidents also consider ideology, use of nominations as a reward for service to the president and the president's party, political benefits that may be gained through a nomination, and the nominee's prospects for confirmation. ${ }^{126}$

The relative weights given to policy and other considerations have varied considerably from president to president and even from nomination to nomination. ${ }^{127}$ Over the Court's history, some presidents have given close attention to the policy preferences of at least some of their nominees, ${ }^{128}$ but they were distinctly in the minority. Our historical analysis focuses on the period since the 1930s, which might be regarded as the beginning of the "modern" era of the Court. ${ }^{129}$

1. From Roosevelt to Fobnson. Franklin Roosevelt (1933-45) gave a high priority to policy considerations in his Supreme Court appoint-

\footnotetext{
${ }^{125}$ Grossman and Hopkins, Asymmetric Politics (cited in note 77).

${ }^{126}$ Lawrence Baum, The Supreme Court 35-40 (CQ Press, 12th ed 2015).

127 See generally, Henry J. Abraham, Fustices, Presidents, and Senators: A History of U.S. Supreme Court Appointments from Wasbington to Bush II (Rowman and Littlefield, 2007).

${ }^{128}$ Presidents who seem to fit that description include Jefferson (see id at 70), Theodore Roosevelt (id at 124), and Taft (id at 131). The two appointments by Ulysses S. Grant to achieve reversal of the Court's first Legal 'Tender decision are another example of policyoriented choices. Robert G. McCloskey and Sanford Levinson, The American Supreme Court 76 (Chicago, 2005). The decisions were Hepburn v Griswold, 8 Wall 603 (1870), and Knoxv Lee, 12 Wall 457 (1871).
}

${ }^{129}$ McCloskey and Levinson, The American Supreme Court at 121-47 (cited in note 128). 
ments. Specifically, he responded to Court rulings invalidating New Deal initiatives ${ }^{130}$ by nominating Justices who seemed likely to support broad interpretations of federal power over the economy. ${ }^{131}$ The Roosevelt appointees diverged considerably on civil liberties issues, however. This may be partially due to the fact that Roosevelt's Democratic Party largely rejected liberalism on civil liberties, as it would have likely alienated important voting blocs. ${ }^{132}$ Further, in contrast with economic policy, civil liberties were only beginning to become prominent on the Court's agenda and, in any event, were not a priority for Roosevelt. ${ }^{133}$

Policy considerations were less important to the next three Democratic presidents, Harry Truman (1945-53), John Kennedy (1961-63), and Lyndon Johnson (1963-69). Although Roosevelt chose nominees primarily from his circle of personal and political acquaintances, ${ }^{134}$ his Democratic successors gave even more weight to their personal and political ties with prospective nominees to the Court. Ideology clearly played a secondary role.

This was especially true of Truman, who gave particular emphasis to personal ties with nominees. ${ }^{135}$ Because of his indifference to ideological considerations, the liberal Truman appointed four relatively conservative Justices to the Court. ${ }^{136}$ Personal connections also

\footnotetext{
${ }^{130}$ Jeff Shesol, Supreme Power: Franklin Roosevelt vs. The Supreme Court (W. W. Norton, 2011).

${ }^{131}$ Leuchtenburg, The Supreme Court Reborn at 154 (cited in note 31).

${ }^{132}$ See Hans Noel, Political Ideologies and Political Parties in America 37 (Cambridge, 2013).

${ }^{133}$ See notes 51-53 and accompanying text (highlighting divergent views of Roosevelt appointees on civil liberties). See generally Pritchett, The Roosevelt Court (cited in note 44); C. Herman Pritchett, Civil Liberties and the Vinson Court (Chicago, 1954).
}

${ }^{134}$ "Nearly all of the Justices chosen by Presidents Franklin Roosevelt, Truman, Kennedy, and Johnson had at least a fairly confidential relationship with them prior to their appointment." Robert Scigliano, The Supreme Court and the Presidency 95 (Free Press, 1971).

${ }^{135}$ In one leading analysis of presidents' appointment strategies, the chapter on Truman is entitled "Truman Rewards Loyalty and Friendship." David Alistair Yalof, Pursuit of Fustices: Presidential Politics and the Selection of Supreme Court Nominees 20-40 (Chicago, 1999). Truman was a party-centrist whose main concern was presiding over a factionalized Democratic Party. See Nelson Lichtenstein, From Corporatism to Collective Bargaining: Organized Labor and the Eclipse of Social Democracy in the Postwar Era, excerpted in Steve Fraser and Gary Gerstle, eds, The Rise and Fall of the New Deal Order, 1930-1980, 122-52 (Princeton, 1989).

${ }^{136}$ Based on the coding of votes in the Supreme Court Database (see note 28), all four Truman appointees ranked above the median among Justices serving in the 1937-2006 Terms for their proportions of conservative votes. With the exception of Clark, all were well above the median. Landes and Posner, $1 \mathrm{~J}$ Legal Analysis at 782-83 (cited in note 31). Among Justices who served in the 1946-85 Terms, the Truman appointees have similar rankings in civil liberties cases, with voting scores modified in an effort to take into account change in the 
explain John F. Kennedy's appointments of Byron White and Arthur Goldberg. Both were members of his Cabinet, and Kennedy had long-standing ties with White. Indeed, White wrote the intelligence report on the sinking of a boat that Kennedy piloted during World War II. ${ }^{137}$

Lyndon Johnson also had close ties to Abe Fortas, whom he appointed to the Court in 1965 and unsuccessfully nominated for Chief Justice three years later, and to Homer Thornberry, whose 1968 nomination became moot when Fortas failed to win confirmation as Chief Justice. Both were personal friends of Johnson, and Fortas served Johnson as an informal but close advisor. ${ }^{138}$ Thurgood Marshall, appointed to the Court in 1967, was Johnson's Solicitor General, and his appointment also reflected the political value of choosing the first African American Justice.

While Truman may have been indifferent to ideology in choosing nominees, Kennedy and Johnson were not. Kennedy, for example. considered elevating federal judge William Hastie to the Supreme Court; had Hastie been nominated and confirmed, he would have become the first African American Justice. But Kennedy chose not to make the nomination, and it appears that Hastie's relative moderation played a role in that decision. ${ }^{139}$

In general, though, these presidents did not emphasize ideology in their selection of Justices. There was therefore considerable room for variation in the ideological orientations of their nominees. Largely because the Democratic Party of that era included many conservative southerners, it was ideologically heterogeneous. ${ }^{140}$ Although the Justices appointed by Democratic presidents from Roosevelt through Johnson tended on average to be fairly liberal, the relatively low priority that most of those presidents gave to ideology resulted in a set of Justices who were mixed in their ideological views.

composition of cases over time. Lawrence Baum, Comparing the Policy Positions of Supreme Court Fustices from Different Periods, 42 Western Pol Q 509, 511 (1989).

${ }^{137}$ Henry J. Abraham, fustices and Presidents 275 (Rowman and Littlefield, 2d ed 1985).

${ }^{138}$ Laura Kalman, Abe Fortas: A Biography 199-227 (Yale, 1990).

${ }^{130}$ Sheldon Goldman, Picking Federal fudges: Lower Court Selection from Roosevelt Through Reagan 166 (Yale, 1999).

${ }^{1+0}$ See Stefanie A. Lindquist, David A. Yalof, and John A. Clark, The Impact of Presidential Appointments to the U.S. Supreme Court: Cohesive and Divisive Voting within Presidential Blocs, 53 Pol Res Q 795 (2000). 
2. Clinton and Obama. Bill Clinton (1993-2001) and Barack Obama (2009-17) each made two appointments to the Supreme Court. The Clinton-Obama approach differed considerably from that of Truman, Kennedy, and Johnson. Clinton and Obama were careful to select nominees whose records gave strong evidence of liberalism. Clinton, for example, drew from "a pool of mostly liberal and Democratic candidates" and seriously considered liberal criticisms of Ginsburg's position on abortion. ${ }^{141}$ Before choosing Sonia Sotomayor in 2009, Obama read long memoranda on the leading candidates and "kept asking for more original writings by the candidates."142

Nonetheless, ideology did not play a determinative role in the Clinton and Obama nominations. Instead, both presidents veered away from nominees whose strong liberalism would prompt confirmation battles and toward nominees who embraced the rhetoric of judicial restraint, had rich personal histories, and were perceived as relatively moderate in their views. ${ }^{1+3}$ When nominating Merrick Garland to fill Antonin Scalia's seat, for example, Obama was well aware of Senate

\footnotetext{
${ }^{141}$ Yalof, Pursuit of fustices at 196 (cited in note 135). See also Jeffrey Toobin, The Nine: Inside the Secret World of the Supreme Court 70-71 (Anchor, 2007). At the same time, Clinton identified as a centrist "New Democrat," and disavowed several liberal positions. See Grossman and Hopkins, Asymmetric Politics at 225-26 (cited in note 77).

${ }^{142}$ Peter Baker and Adam Nagourney, Tight Lid Defined Process in Selecting a New Fustice, NY Times at A17 (May 28, 2009).

${ }^{143}$ On Ginsburg, see Elizabeth Drew, On the Edge: The Clinton Presidency 217-18 (Touchstone, 1995); Toobin, The Nine at 70 (cited in note 141). Clinton also thought it important that Ginsburg was championed by Senator Daniel Patrick Moynihan (D-NY), who held considerable influence over proposed health care legislation. Id. On the unhappiness of some liberals about Breyer's appointment, see Jan Crawford Greenburg, Supreme Conflict: The Inside Story of The Struggle for Control of The United States Supreme Court 182 (Penguin, 2007). On Breyer's ties to influential Republicans, see Drew, On the Edge at 214. On Obama's appointments, see Peter A. Baker, Favorites of Left Don't Make Obama's Court List, NY Times at A12 (May 26, 2009), and Jeffrey 'Toobin, Bench Press: Are Obama's fudges Really Liberal?, New Yorker (Sept 21, 2009). More generally, Obama "paid less attention" to the opportunity to use judicial appointments to appoint young lawyers who "could make significant marks on the law" than did Ronald Reagan and his Republican successors. Jeffrey Toobin, Obama's Unfinisbed fudicial Legacy, New Yorker (July 31, 2012), available at http://www.newyorker.com/news/daily-com ment/obamas-unfinished-judicial-legacy.

Scores developed by Jeffrey Segal and Albert Cover measure perceptions of Supreme Court nominees' ideological positions in newspaper editorials after their nominations. The scores range from 0.0 at the conservative end to 1.0 at the liberal end. The Segal-Cover scores for these four nominees underline the difference: .680 for Ginsburg, .475 for Breyer, .780 for Sotomayor, and .730 for Kagan. By contrast, Roberts's score was .120 and Alito's .100. See Jeffrey A. Segal and Albert D. Cover, Ideological Vahues and the Votes of U.S. Supreme Court fustices, 83 Am Pol Sci Rev 557 (1989). The scores can be found at http://www.stonybrook.edu/polsci/jsegal/.
} 
Republican threats to derail any nomination. ${ }^{144}$ Acknowledging that Garland was "just the right nominee during such a divisive time in our politics," 145 Obama selected a sixty-three-year-old moderate-liberal who stood a better chance of confirmation than any other candidate. ${ }^{146}$ Reflecting the tendency of Democrats to place interest group politics ahead of ideology, ${ }^{147}$ Clinton and Obama also put substantial emphasis on racial and gender diversity in their judicial nominations, including Supreme Court appointments. ${ }^{148}$ As Mark Tushnet has observed, "Democratic presidents tend to pursue a demographic strategy rather than an ideological one for Supreme Court nominations." ${ }^{149}$

One way to characterize the Clinton-Obama appointments is that, in comparison with the appointments of earlier Democratic administrations, the average ideological position has not changed a great deal, but the variation has been reduced. Unlike earlier Democrats (who appointed both strong liberals and conservatives), the Clinton-

${ }^{1+4}$ See Gregory Korte, How Obama Picked Merrick Garland for Last Supreme Court Pick, USA Today (March 17, 2016), available at http://www.usatoday.com/story/news/politics /2016/03/16/white-house-garland-obamas-first-choice-supreme-court/81866606/; Lawrence Baum and Neal Devins, Ideological Imbalance: Why Democrats Usually Pick Moderate-Liberal Fustices and Republicans Usually Pick Conservative Ones, Slate (March 17, 2016), available at http://www.slate.com/articles/news_and_politics/jurisprudence/2016/03/democrats_always _pick_moderates_like_merrick_garland.html.

${ }^{145}$ Korte, How Obama Picked Merrick Garland (cited in note 144) (quoting Deputy White House Press Secretary Eric Schultz).

${ }^{146}$ See Adam Liptak, Where Merrick Garland Stands: A Close Look at His Fudicial Record, NY Times (March 17, 2016), available at http://www.nytimes.com/2016/03/18/us/politics /merrick-garlands-record-and-style-hint-at-his-appeal.html; Matthew Yglesias, The Real Reason President Obama Appointed Merrick Garland, Vox (March 18, 2016), available at http:// www.vox.com/2016/3/18/11261416/why-obama-picked-garland. For a similar assessment of why Hillary Clinton might have reappointed Garland, see Joan Biskupic, Wby Merrick Garland Sbould Keep Hoping, CNN Politics (Oct 23, 2016), available at http://www.cnn.com/2016 /10/23/politics/hillary-clinton-merrick-garland-supreme-court/.

${ }^{147}$ See Matt Grossman and David A. Hopkins, Ideological Republican and Group Interest Democrats, 13 Persp on Pol 119 (2015). Democrats are limited in their pursuit of ideology, in part, because Democrats are not dominated by a single interest group; instead, Democrats advance the interests of a pro-government coalition that includes interest groups interested in the environment, economic inequality, race, and much more. See id at 119-20, 134-35.

${ }^{148}$ See Jeffrey Toobin, Obama's Unfinished Judicial Legacy, New Yorker (July 31, 2012), available at http://www.newyorker.com/news/daily-comment/obamas-unfinished-judicial-legacy (noting that "half of [Obama's] successful nominees have been women (compared to twenty-three per cent for Bush II), and nineteen per cent have been African American (compared to seven per cent for Bush II)"); Sheldon Goldman and Matthew D. Saronson, Clinton's Non-Traditional fudges: Creating a More Representative Branch, 78 Judicature 68 (1994).

${ }^{149}$ Tushnet, In the Balance at 74 (cited in note 21). 
Obama appointees were all moderate liberals. A measure of Justices' ideological positions by year that was devised by Michael Bailey confirms this conclusion. ${ }^{150}$ His measure pertains to civil liberties cases and covers the period from 1951 to 2011. A score of 1.22 is the most conservative in a particular year for any Justice in his study, and -1.87 the most liberal. ${ }^{151}$ For the Democratic appointees who served during the study period, the average of their mean scores across terms was -0.55 for the Obama and Clinton appointees and -0.24 , a little less liberal, for the Justices appointed by the presidents from Roosevelt to Johnson. But the Clinton and Obama appointees were clustered together, with a standard deviation of only .09 in their scores; ${ }^{152}$ in contrast, their predecessors had a standard deviation of 1.03. Of the thirteen pre-Clinton Democratic appointees, five were more liberal than any of the Clinton and Obama Justices, and eight were more conservative than any of them. Thus, the Obama and Clinton appointees have contributed to partisan polarization of the Court by standing on the liberal side of the ideological spectrum, but they have adhered to a position of moderate rather than strong liberalism. More to the point, recent Democratic appointees to the Court do not reflect the sharp leftward shift of Democratic elites discussed in Part II. Instead, because Clinton and Obama valued interest group politics as much as ideology, they did not appoint strong liberals to the Court. Indeed, none of their nominees was as liberal as William O. Douglas, Earl Warren, William J. Brennan, Abe Fortas, Arthur Goldberg, or Thurgood Marshall.

\footnotetext{
${ }^{150}$ The scores are compiled at http://faculty.georgetown.edu/baileyma/JOPIdealPointsJan 2013.htm. The method for creating them is discussed in Michael A. Bailey, Is Today's Court the Most Conservative in Sixty Years? Challenges and Opportunities in Measuring Fudicial Preferences, 75 J Pol 821 (2013). Because these scores were compiled only through calendar year 2011, only two terms are available for Justice Sotomayor and one term for Justice Kagan, but the stability of their voting records relative to their colleagues since that time indicates that their scores over a more extended period would be similar.

${ }^{151}$ Calculations in this paragraph were prepared by the authors based on scores compiled by Bailey.

${ }^{152}$ Obama's March 2016 nomination of Merrick Garland conforms to this practice. See Baum and Devins, Ideological Imbalance (cited in note 144). For example, ideological measures of Garland locate him smack in the middle of Clinton-Obama Democratic appointees. See Adam Liptak and Alicia Palapiano, How Clinton's or Trump's Nominees Could Affect the Balance of the Supreme Court, NY Times (Sept 25, 2016), available at http://www.nytimes.com/in teractive/2016/09/25/us/politics/how-clintons-or-trumps-nominees-could-affect-the-bal ance-of-the-supreme-court.html?_r $=0$.
} 


\section{B. REPUBLICAN PRESIDENTS}

The changes in appointment strategies on the Republican side have been more dramatic. That difference reflects a more fundamental change in the role of ideology in the Republican Party.

1. From Eisenhower to Ford. In contrast with Democratic presidents during the period from the 1930s through the 1960s, Republicans Dwight Eisenhower and Gerald Ford focused neither on personal relationships with nominees nor on policy considerations. Eisenhower named Earl Warren Chief Justice in 1953 to pay back a political debt for crucial support that the Warren-led California delegation had provided to him at the 1952 Republican Party convention. ${ }^{153}$ The choice of William Brennan in October 1956 was motivated primarily by the perceived electoral advantages of choosing a Catholic Democrat. $^{154}$

Gerald Ford's appointment of John Paul Stevens in 1975 was unusual in that personal, political, and ideological considerations played essentially no role in his decision. Ford delegated the selection of a nominee to Attorney General Edward Levi, asking him to focus on the qualifications of prospective nominees. Ford's approach can be understood in part as a response to Watergate, and especially to abuses in the Justice Department. ${ }^{155}$

President Richard Nixon's approach was more ambiguous. When running for president in 1968, Nixon sharply criticized the decisions of the Warren Court. ${ }^{156}$ Once in office, Nixon sought to woo con-

${ }^{153}$ Abraham, 7ustices and Presidents at 200-02 (cited in note 137); Yalof, Pursuit of Fustices at 44-45 (cited in note 135).

${ }^{154}$ Christine L. Nemacheck, Strategic Selection: Presidential Nomination of Supreme Count 7ustices from Herbert Hoover Through George W. Bush 49 (Virginia, 2007); Abraham, Fustices and Presidents at 208 (cited in note 137); Yalof, Pursuit of fustices at 55-56, 61 (cited in note 135). The Segal-Cover scores for Warren and Brennan were .750 and 1.000 , respectively. Segal and Cover, $83 \mathrm{Am}$ Pol Sci Rev (cited in note 143). Eisenhower's disappointment with Warren and Brennan led him to give attention to ideology in his second-term appointments of Charles Whittaker (1957) and Potter Stewart (1958), but even in those instances the policy preferences of prospective nominees were considered to only a limited degree. Yalof, Pursuit of fustices at 61-69 (cited in note 135).

${ }^{155}$ Yalof, Pursuit of Fustices at 125-31 (cited in note 135); Abraham, Fustices, Presidents, and Senators at 160-61 (cited in note 127). Levi and Stevens did have a long personal relationship, dating back to elementary school. George L. Priest and William Ranney Levi, Fustice Stevens, Edward Levi, and the Chicago School of Antitrust, Nat'l L Rev (May 24, 2010), available at http://www.law.uchicago.edu/news/Justice-stevens-edward-levi-and-chicago-school-anti trust.

${ }^{156}$ Donald Grier Stephenson, Jr., Campaigns and the Court: The U.S. Supreme Court in Presidential Elections 179-82 (Columbia, 1999). 
servatives to the Republican Party by emphasizing several policy concerns, including criminal justice and school busing, relating to the Court. ${ }^{157}$ At the same time, though, Nixon was careful not to alienate northern moderates who were still important to the Republican Party. Nixon's Supreme Court appointments reflected those sometimes conflicting goals: he sought Justices with conservative positions on the issues that were politically important to him, but he sought "ideological conformity" only on criminal justice and busing, and he was not interested in appointing a "hardliner." 158 In other words, "politics far more than ideology drove all six of [Nixon's] choices for the Court." 159

2. From Reagan to George W. Bush. The Reagan administration broke ranks with its predecessors by making ideological considerations "the most important criteria" in the screening of judicial candidates, seeking to reshape Supreme Court decision making by sponsoring "ardently conservative candidates to the high court." ${ }^{60}$ Unlike Roosevelt, who focused specifically on economic regulation, and Nixon, who focused specifically on criminal justice and school busing, Reagan sought to fundamentally transform the role of the Supreme Court. ${ }^{161}$ Ideology played a dominant role in his nominations of such conservative stalwarts as Antonin Scalia, Robert Bork, Douglas Ginsburg, and (as Chief Justice) William Rehnquist. ${ }^{162}$

\footnotetext{
${ }^{157}$ Kevin J. McMahon, Nixon's Court: His Cballenge to Fudicial Liberalism and Its Political Consequences (Chicago, 2011).

${ }^{158}$ Eric A. Posner, Casual with the Court, New Republic (Oct 24, 2011), at https:// newrepublic.com/article/94516/nixons-court-kevin-mcmahon (reviewing McMahon, Nixon's Court (cited in note 157)).

${ }^{159}$ McMahon, Nixon's Court at 6 (cited in note 157). Nixon White House Counsel John Dean's account of the chaotic process through which several of the Nixon nominations were made also underlines the lack of a systematic effort to choose nominees on the basis of their policy positions. See John W. Dean, The Rebnquist Choice: The Untold Story of the Nixon Appointment That Redefined the Supreme Court (Free Press, 2002).

${ }^{160}$ Yalof, Pursuit of fustices at 134 (cited in note 135).

${ }^{161}$ See Keith E. Whittington, Political Foundations of Fudicial Supremacy: The Presidency, the Supreme Court, and Constitutional Leadership in U.S. History 89 (Princeton, 2009). See also John C. Hughes, The Federal Courts, Politics, and the Rule of Law 74 (Harpercollins, 1995) (claiming that Reagan had been elected on a wave of conservative populism, and he "could not afford to be indifferent to the courts").

${ }^{162}$ See Yalof, Pursuit of fustices at 142-65 (cited in note 135). All four had markedly conservative records on the federal appellate courts. Reflecting perceptions of those records, the Segal-Cover scores (Segal and Cover, 83 Am Pol Sci Rev (cited in note 143)) for the four nominees were all below .100 .
} 
Ideology also played a central role in the appointment strategies of Republicans George H. W. Bush and George W. Bush. George H. W. Bush chose Clarence Thomas in part to maintain African American representation on the Court, but Thomas also had a very strong record of conservatism. By nominating John Roberts, Harriet Miers, and Samuel Alito in 2005, George W. Bush sought to select the "most conservative possible Supreme Court Justice." ${ }^{163}$ More striking, he put the desires of conservative leaders ahead of his own preferences. In particular, well-placed staunch conservatives were able to secure the withdrawal of Harriet Miers ${ }^{164}$ —even though she was a trusted personal and political associate of Bush ${ }^{165}$ and someone the president thought was strongly conservative. ${ }^{166}$ Staunch conservatives - especially those for whom abortion was a high priorityhad already succeeded in preventing the nomination of Attorney General Alberto Gonzales, another close associate of the president, for the same seat on the Court. ${ }^{167}$

It is important to note, though, that ideology was not the only criterion that these Republican presidents took into account. In nominating Sandra Day O'Connor, Reagan honored a campaign pledge to nominate a woman, ${ }^{168}$ and when nominating Anthony Kennedy in 1987 and David Souter in 1990, the Reagan and George H. W. Bush administrations went out of their way to avoid potentially bruising confirmation battles. ${ }^{169}$

${ }^{163}$ Toobin, The Nine at 345 (cited in note 141).

${ }^{16+}$ See notes $185-90$ and accompanying text.

${ }^{165}$ Before becoming White House counsel, Miers had served as Bush's personal attorney. See Toobin, The Nine at 286-87 (cited in note 141).

${ }^{166}$ For Bush, Miers was the perfect "stealth" candidate- like David Souter but without the risk. See Steve Holland, Bush Defends Pick for Supreme Court, Toronto Star at A11 (Oct 5, 2005) (quoting Bush as saying "there's not a lot of opinions for people to look at").

${ }^{167}$ Toobin, The Nine at 266-70 (cited in note 141). The importance of the abortion issue in the blocking of a Gonzales nomination and in Miers's nomination is discussed in Geoffrey R. Stone, Sex and the Constitution 423-24 (Liveright, 2017).

${ }^{168}$ Douglas E. Kneeland, Reagan Pledges Women on Court; Carter Challenges Foe on Economy, NY Times at A1 (Oct 15, 1980). On the array of considerations that may have affected the choice of O'Connor, see Nemacheck, Strategic Selection at 9-13 (cited in note 154).

${ }^{169}$ Although administration insiders thought Kennedy and Souter were solid conservatives, they were chosen over more conservative alternatives - and, in Kennedy's case, after two of those alternatives were nominated or announced as a nominee but not confirmed. See Yalof, Pursuit of Fustices at 145-46, 164 (cited in note 135) (discussing Kennedy); James MacGregor Burns, Packing the Court: The Rise of Fudicial Power and the Coming Crisis of the Supreme Court 217 (Penguin, 2009) (discussing Souter). 
Despite these exceptions, the overall shift in emphasis in the appointment strategies of these three Republican presidents was largely the product of the political and judicial priorities of their administrations, priorities that were shaped in no small part by the emergence of a new conservative legal movement.

After Ronald Reagan took office in 1981, the Reagan Justice Department began grooming a cadre of well-credentialed conservative lawyers in an effort to transform both constitutional discourse and judicial decision making. Under the leadership of Attorney General Edwin Meese, the Department of Justice in Reagan's second term sought aggressively to advance conservative goals in the judiciary. ${ }^{170}$ Recognizing that the "project of getting the Constitution right was more than just appointing judges, and that we had to have a rhetoric that was persuasive, and an analysis that became talked about by public intellectuals," 171 Meese formally embraced the "Jurisprudence of Original Intention." ${ }^{172}$ He gave speeches, organized seminars on originalism within the department, and directed his Office of Legal Policy to issue Guidelines for Constitutional Litigation to enable Justice Department attorneys to adhere to the principles of originalism in their legal analyses and arguments. ${ }^{173}$ In these and other ways, Meese sought to "facilitate the orderly development of conservative legal ideals and their injection into the mainstream."174

Meese also sought to staff the Justice Department with young conservative lawyers - making "ideological commitment . . . a credential rather than a disqualification." 175 The recently established Federalist Society was an important component of this strategy, be-

\footnotetext{
${ }^{170}$ Meese became Attorney General in 1985. First-term Attorney General William French Smith also embraced conservative ideals but did not pursue long-term objectives. See William French Smith, Urging 7udicial Restraint, 68 ABA J 59 (1982); Teles, Transformative Bureaucracy at 66-69 (cited in note 10).

${ }^{171}$ Teles, Transformative Bureaucracy at 76 (cited in note 10) (quoting Kenneth Cribb, who served as Counselor to the Attorney General).

${ }^{172}$ Attorney General Edwin Meese, Address Before the American Bar Association, The Supreme Court of the United States: Bulwark of a Limited Constitution (July 9, 1985), available at http://www.fed-soc.org/publications/detail/the-great-debate-attorney-general-ed-meese-iii -july-9-1985. See also Teles, Transformative Bureaucracy at 80-81 (cited in note 10) (noting that the "critical turning point in the development of originalism" was a lunch-time talk by then-D.C. Circuit Judge Antonin Scalia to DoJ political appointees).
}

${ }^{173}$ Teles, Transformative Bureaucracy at 75-82 (cited in note 10).

${ }^{174}$ Teles, Conservative Legal Movement at 136 (cited in note 13).

${ }^{175}$ Teles, Transformative Bureancracy at 74 (cited in note 10). 
cause it enabled Meese and others in the administration to identify promising candidates for positions both in the Department of Justice and on the courts. Meese hired the society's founders as special assistants and tapped Stephen Markman, who headed the Washington, D.C. chapter of the Federalist Society, to become the Assistant Attorney General in charge of judicial selection. ${ }^{176}$

The George H. W. Bush administration followed the Reagan administration's lead. The administration looked to Lee Liberman Otis, co-founder of the Federalist Society, to lead its judicial selection process. ${ }^{177}$ Both administrations aimed to nominate conservative judges, and membership in the Federalist Society was a proxy for adherence to conservative ideology. Reagan made all three of the society's original faculty advisors federal court judges and nominated two of the three-Robert Bork and Antonin Scalia-to the Supreme Court. ${ }^{178}$ Nine of President George H. W. Bush's fifty-five ${ }^{179}$ nominees to the federal courts of appeals and the Supreme Court were Federalist Society members (including Clarence Thomas, Samuel Alito, and John Roberts). ${ }^{180}$

At the same time, the Reagan and George W. Bush administrations were limited in their ability to nominate reliable conservatives. They did not yet have a "farm team" of conservatives who had joined the Federalist Society as law students and cut their teeth either

${ }^{176}$ Id at 68,74 . The Federalist Society was established in 1982 by conservative Yale and University of Chicago law students who felt "alienated from the prevailing political orientation of their classmates and their schools." Avery and McLaughlin, The Federalist Society at 1 (cited in note 118). See also Southworth, Lawyers of the Right at 124-48 (cited in note 116).

${ }^{177}$ Teles, Rise of the Conservative Legal Movement (cited in note 13).

${ }^{178}$ Nancy Scherer and Banks Miller, The Federalist Society's Influence on the Federal Fudiciary, 62 Pol Res Q 366, 367 (2009).

${ }^{179}$ George H. W. Bush nominated fifty-three individuals to U.S. Circuit Courts, see Denis Steven Rutkus et al, Cong Research Serv, RL31868, U.S. Circuit and District Court Nominations by President George W. Bush During the 107tb-109tb Congresses 30 (2007) (listing the number of U.S. Circuit Court nominees of recent presidents), and two individuals to the U.S. Supreme Court, see US Senate, Supreme Court Nominations, present-1789, available at http://www.senate.gov/pagelayout/reference/nominations/ Nominations.htm.

${ }^{180}$ Id. (Roberts's 1992 nomination was not acted on by the Senate. Alito was confirmed to the Third Circuit, Thomas to the D.C. Circuit and Supreme Court.) At the time of Roberts's 2005 nomination to the Supreme Court, there was some uncertainty about whether he had ever been an official member of the Federalist Society, and Roberts reported that he did not remember being a member. Charles Lane, Federalist Affiliation Misstated; Roberts Does Not Belong to Group, Wash Post at A16 (July 21, 2005); Charles Lane, Roberts Listed in Federalist Society '97-98 Directory; Court Director; Court Said He Has No Memory of Membership, Wash Post at A1 (July 25, 2005). But Roberts has had ties with the society since his Supreme Court appointment. 
clerking for a conservative judge or working as a government attorney. As Reagan Justice Department official Richard Willard explained, "these were the days before the Federalist Society was really off the ground, so it was hard to find lawyers who had a conservative political outlook. At that time, the law schools and the professional associations were overwhelmingly liberal in their outlook, and so finding conservative lawyers who had the outlook, but also the professional competence, to do the job, was a challenge." 181

By the time George W. Bush became president in 2001, though, the conservative legal movement dominated Department of Justice and judicial appointments. Not only did Federalist Society members play "key roles in selecting, vetting, and shepherding nominees through the confirmation process" during the George W. Bush administration, but legal positions in the administration were overwhelmingly filled by members of the Federalist Society. ${ }^{182}$ The administration tapped Federalist Society members Brett Kavanaugh and Viet Dinh to be in charge of judicial selection. ${ }^{183}$ By 2005, the "farm team" of credentialed conservatives included John Roberts and Samuel Alito, and approximately half of George W. Bush's appointees to the federal courts of appeals were members of the Federalist Society. ${ }^{184}$

The nomination and withdrawal of Supreme Court nominee Harriet Miers vividly illustrates both the power of the conservative legal movement and the depth of the current pool of potential conservative Supreme Court nominees. Determined "not to repeat his father's mistake with Souter," Bush had the backing of Leonard Leo, the executive vice president of the Federalist Society. ${ }^{185}$ Nonetheless, the reaction to the Miers nomination from the conservative legal

\footnotetext{
${ }^{181}$ Quoted in Teles, Transformative Bureaucracy at 70-71 (cited in note 10). See also id at 73 (noting Kenneth Cribb's comment to Attorney General Meese that "there aren't enough gray haired people who agree with us" to staff critical positions).

${ }^{182}$ Hollis-Brusky, Ideas with Consequences at 154 (cited in note 13). According to Daniel Troy, Federalist Society member and Bush-appointed counsel to the FDA, "Everybody, I mean everybody who got a job who was a lawyer was involved with the Federalist Society. I mean everybody." Id (quoting Troy).

${ }^{183}$ Michael Avery and Danielle McLaughlin, How Conservatives Captured the Laww, Chron Higher Educ (Apr 15, 2013).

${ }^{184} \mathrm{Id}$; Scherer and Miller, 62 Pol Res Q at 368 (cited in note 178) (noting that around twothirds of Bush's first-term judicial nominees were Federalist Society members).

${ }^{185}$ Greenburg, Supreme Conflict at 265 (cited in note 143).
} 
establishment was "immediate, harsh, and pointed." ${ }^{186}$ Attacking her both for her lack of Federalist Society "credentials" ${ }^{187}$ and for her ties to the American Bar Association (which conservatives had turned against as too liberal in its screening of judges), ${ }^{188}$ conservatives demanded that Miers withdraw and be replaced by a nominee from the "deep farm team of superbly qualified and talented circuit court judges primed for this moment." ${ }^{189}$ Twenty-four days after her nomination, with conservative criticism unabated, Miers withdrew. Her replacement was Samuel Alito-a Federalist Society member and the favorite of the very conservatives who had attacked Miers. ${ }^{190}$

With four Federalist Society members sitting on the Supreme Court from 2006 to 2016 , there is little question that the society has become a "mediating institution" for legal conservatives, helping to maintain "channels of communication through which individuals and organizations can exercise political influence." ${ }^{191}$ Indeed, when 2016 Republican presidential candidate Donald Trump sought to establish his bona fides with the conservative legal network, he consulted with Federalist Society leadership in assembling his lists of potential Su-

${ }^{186}$ Teles, Conservative Legal Movement at 1 (cited in note 13). See generally Greenburg, Supreme Conflict at 263-84 (cited in note 143).

${ }^{187}$ See Hollis-Brusky, Ideas with Consequences at 153 (cited in note 13) (quoting Federalist Society member Tony Cotto as saying "No Fed Society credentials, that's going to hurt you. It hurt Harriet [Miers] a lot.... We want credentials. We want to see you've spoken at Federalist Society conferences, we want to know you've been to dinners, gripping and grinning").

${ }^{188}$ On Miers's ties to the ABA, see Miers $v$ The Federalist Society, Daily Kos (Oct 7, 2005, 2:53 p.m.), archived at http://www.dailykos.com/story/2005/10/07/155092/-Miers-v-The-Fed eralist-Society (quoting a post on the Volokb Conspiracy by Jim Lindgren). On conservative disapproval of the $\mathrm{ABA}$ (including the George $W$. Bush administration's refusal to seek $\mathrm{ABA}$ screening of judicial nominees), see Teles, Conservative Legal Movement at 167-73 (cited in note 13).

${ }^{189}$ Todd Zywicki, A Great Mind, 28 Legal Times (Oct 10, 2005), archived at https://perma .cc/LHK7-2JGB. See also Randy E. Barnett, Cronyism, Wall St J, A26 (Oct 5, 2005) (suggesting that Miers lacked "a firm grasp on constitutional text, history and principles" as well as the ability to "resist the severe pressure brought by Congress, by the executive branch, by state and local governments, and also by fellow Justices to exceed the Constitution's limits on government power"); Michael A. Fletcher and Charles Babington, Miers, Under Fire from Right, Withdrawn as Court Nominee, Wash Post (Oct 28, 2005), archived at https://perma.cc X7MP-EMAW.

${ }^{190}$ See Greenburg, Supreme Conflict at 269-70 (cited in note 143) (recounting story of former Reagan official Mike Carvin's strong support of Alito and opposition to Miers); see also Peter Baker, Alito Nomination Sets Stage for Ideological Battle, Wash Post (Nov 1, 2005), archived at https://perma.cc/9D5E-92UA ("Conservative leaders who helped force Miers to pull out Thursday rejoiced at the selection, seeing in Alito the philosophical equivalent of Justice Antonin Scalia.").

${ }^{191}$ Southworth, Lawyers of the Right at 135, 141 (cited in note 116). 
preme Court nominees. ${ }^{192}$ And when the society held its annual National Lawyers Convention a week after the 2016 election, nine of the twenty-one judges on that list were among the speakers and "nearly all the others" were in attendance. ${ }^{193}$ Today, membership in the Federalist Society is critical to the credentialing of conservative lawyers. Michael Greve put it this way: "[O]n the left there are a million ways of getting credentialed; on the political right there's only one way in these legal circles."194

\section{The Justices in Their Social Environments}

In this part, we focus on the social environments of the Justices, that is, the individuals and groups with whom the Justices interact directly or indirectly and whose regard the Justices care about. We argue that a Justice's social environment can exert significant influence on his or her jurisprudence.

\section{A. THE JUSTICES' SOCIAL IDENTITIES}

In addition to the goal of making sound legal decisions, Supreme Court Justices have other interests and values that affect their judicial behavior. ${ }^{195}$ Like other people, they have social identities, ${ }^{196}$ and

\footnotetext{
${ }^{192}$ See Alan Rappeport and Charlie Savage, Donald Trump Releases List of Possible Supreme Court Picks, NY Times (May 18, 2016), available at http://www.nytimes.com/2016/05/19/us /politics/donald-trump-supreme-court-nominees.html?_r=0; Bob Woodward and Robert Costa, In a Revealing Interviezv, Trump Predicts a Massive Recession but Intends to Eliminate the National Debt in 8 Years, Wash Post (April 2, 2016), available at https://www.washingtonpost .com/politics/in-turmoil-or-triumph-donald-trump-stands-alone/2016/04/02/8c0619b6 -f8d6-11e5-a3ce-f06b5ba21f33_story.html (quoting Trump as saying "I'm getting names, The Federalist people. Some very good people.").

${ }^{193}$ Richard Wolf, Supreme Court Wannabes Audition, USA Today (Nov 21, 2016), 5A.

${ }^{194}$ Quoted in Hollis-Brusky, Ideas with Consequences at 152 (cited in note 13). It is for this very reason that the Federalist Society can have a de facto monopoly on the credentialing of the right, whereas the American Constitution Society cannot occupy a similar role on the left. The liberal legal establishment is far too large for any one group to truly capture Democratic judicial appointments.

${ }^{195}$ Baum, fudges and Their Audiences at 1-24 (cited in note 11); Frederick Schauer, Incentives, Reputation, and the Inglorious Determinants of 7udicial Bebavior, $68 \mathrm{U}$ Cin L Rev 615, 619-21 (2000). For this reason, we take issue with political science models that assume that the Justices are single minded in their pursuit of their preferred legal policy agenda. See Baum and Devins, 98 Georgetown L J at 1529-32 (cited in note 12) (discussing these political science models and our critique of them).

${ }^{196}$ On social identities generally, see Henry Tajfel, Differentiation Between Social Groups: Studies in the Social Psychology of Intergroup Relations (1978); Marilynn B. Brewer, The Many Faces of Social Identity: Implications for Political Psychology, 22 Pol Psychol 115 (2001).
} 
they care about how they are regarded by people who are important to those identities. Family members, friendship networks, and other relationships that relate to Justices' social identities serve as reference groups. ${ }^{197}$

Indeed, people who are interested in becoming federal appellate judges are likely to be more interested in the esteem of others than are most other people. ${ }^{198}$ Such individuals willingly accept reduced monetary compensation and constraints on their personal activities and behaviors in exchange for the power and esteem that attach to a position on the federal bench. ${ }^{199}$ Moreover, the high level of public attention that Supreme Court Justices receive today heightens their incentive to attain positive reputations with those whose esteem they most care about. Certainly, today's Justices invest substantial energy in cultivating their image with outside audiences. In terms of the number of extrajudicial appearances and interviews Justices have per year, one study shows that, in the years since 1960, the nine current Justices are all in the top ten. ${ }^{200}$ It is therefore reasonable to posit that a desire for the esteem of others affects the Justices' behavior as decision makers.

As some scholars have posited, some Justices seem to care a good deal about how they are regarded by the American people as a whole. ${ }^{201}$ But Justices generally orient themselves more specifically toward the political, legal, and social elite groups to which they belong: ${ }^{202}$ No doubt, the elite audiences that are particularly important to individual Justices differ, but the Justices' personal backgrounds

\footnotetext{
${ }^{197}$ Moreover, Supreme Court Justices are often associated with one or the other political party; many have worked for Democratic or Republican administrations and most have contributed to political parties. Correspondingly, recent social science evidence links partisanship to the composition of the federal bench, including the fact that most federal court of appeals judges contributed to political campaigns before their appointment. See Adam Bonica and Maya Sen, The Politics of Selecting the Bench from the Bar: The Legal Profession and Partisan Incentives to Politicize the 7udiciary (Harv Kennedy School, Working Paper No RWP 15-001, 2015), archived at https://perma.ce/CS5V-2VCD.

${ }^{198}$ Baum and Devins, 98 Georgetown L J at 1532 (cited in note 12). Judges' interest in the esteem of other people is discussed in Thomas J. Miceli and Metin M. Cosgel, Reputation and Fudicial Decision-making, 23 J Econ Behav \& Org 31 (1994), and in Schauer, 68 U Cin L Rev at 625-31 (cited in note 195).

${ }^{199}$ See Baum and Devins, 98 Georgetown L J at 1532 (cited in note 12).

${ }^{200}$ See Richard L. Hasen, Celebrity fustice: Supreme Court Edition 9 (U.C. Irvine School of Law, Research Paper No 2015-61, 2016), archived at https://perma.cc/3CZG-ZLS3.

${ }^{201}$ Friedman, The Will of the People (cited in note 94); Jeffrey Rosen, The Most Democratic Branch: How the Courts Serve America (Oxford, 2006).

${ }^{202}$ Baum and Devins, 98 Georgetown L J (cited in note 12).
} 
and positions make some audiences especially relevant. In particular, today's Justices are members of increasingly polarized elite social networks that help to create and reinforce their ideological commitments. ${ }^{203}$ These competing networks have replaced the relatively consensual center-left social network that once helped shape the thinking of both Republican and Democratic appointees to the Court. In part because of this change, Justices appointed to the Court by Republican presidents since 1990 have been less likely to support liberal positions than pre-1990 Republican appointees. The change has had less impact on the Democratic side, because Justices appointed by Democratic appointees were part of social networks that leaned to the left even before the era of strong polarization.

\section{B. REPUBLICAN APPOINTEES TO THE COURT: FROM THE I95OS TO THE I $99 O S$}

In their votes and opinions, several of the Republican appointees to the Supreme Court between 1950 and 1990 were more liberal than some Democratic appointees. ${ }^{20+}$ As noted in Part III, Republican presidents' appointment strategies help to explain this phenomenon. ${ }^{205}$ But as early as the 1960 s, when President Nixon complained about the liberalizing influence of the "Washington-Georgetown social set" on certain Justices, ${ }^{206}$ some observers maintained that a milieu of people and groups that shared liberal values, especially on civil liberties issues, influenced the behavior of the Justices. This milieu included the American Bar Association, legal academics, Supreme Court reporters, and elite social circles in Washington, D.C. ${ }^{207}$ According to this narrative, Justices who came to the Court as con-

\footnotetext{
${ }^{203}$ Justice Scalia described one result: "It's a nasty time. When I was first in Washington, and even in my early years on this Court, I used to go to a lot of dinner parties at which there were people from both sides. Democrats, Republicans. [Washington Post publisher] Katharine Graham used to have dinner parties that really were quite representative of Washington. It doesn't happen anymore." Jennifer Senior, In Conversation: Antonin Scalia, 22, 27 NY Mag (Oct 14, 2013).

${ }^{204}$ See Section I.B. For a discussion of conservative disappointment in such appointments, see Marc A. Thiessen, Why Are Republicans So Awfful at Picking Supreme Court Fustices?, Wash Post (July 2, 2012), archived at https://perma.cc/R52G-YHTM.

${ }^{205}$ See Section III.B.

${ }^{206}$ Richard Reeves, President Nixon: Alone in the White House at 338 (Simon \& Schuster, 2001); John W. Dean, The Rebnquist Choice at 171 (Free Press, 2001).

${ }^{207}$ On the components of this milieu within the legal profession, see Teles, Conservative Legal Movement at 22-57 (cited in note 13).
} 
servatives often moved to the left during their tenure on the Court in order to please this left-leaning audience. ${ }^{208}$ Indeed, Justice Antonin Scalia adopted this narrative in his opinions, complaining of what he saw as his colleagues' undue responsiveness to the views of a liberal elite. ${ }^{209}$

To determine whether some Republican appointees actually moved to the left during their tenure on the Court, we begin by comparing the Justices' voting records from early in their tenure with their records in later years. Such comparisons are very difficult, because shifts in the Court's agenda can create an impression of ideological change (or, for that matter, an impression of stability) that is illusory. ${ }^{210}$ But imperfect measures ${ }^{211}$ do support claims of leftward movement by

${ }^{208}$ Economist and columnist Thomas Sowell and two conservative federal judges have posited that impact with particular clarity. Thomas Sowell, Fustice Kennedy Goes Soft on Crime, Columbus Dispatch A11 (Aug 13, 2003); Sowell, Blackmun Plays to the Crowd at 7B (cited in note 115); Attacking Activism at 14 (cited in note 115); Robert H. Bork, Again, a Struggle for the Soul of the Court, NY Times A19 (July 8, 1992).

${ }^{209}$ Romer v Evans, 517 US 620, 636 (1996) (Scalia, J, dissenting); United States v Virginia, 518 US 515, 567 (1996) (Scalia, J, dissenting); Lanvrence v Texas, 539 US 558, 602 (2003) (Scalia, J, dissenting); Obergefell v Hodges, 135 S Ct 2584, 2629 (2015) (Scalia, J, dissenting).

${ }^{210}$ See Kevin T. McGuire and James A. Stimson, The Least Dangerous Branch Revisited: New Evidence on Supreme Court Responsiveness to Public Preferences, 66 J Pol 1018, 1023-27 (2004).

${ }^{211}$ The measures employed for this discussion include the simple proportions of pro-civil liberties votes by Justices in their fifth through tenth terms, compared with their first and second terms, reported in Baum, fudges and Their Audiences at 147 (cited in note 11); the same proportions, but with an adjustment for change in the Court's agenda, reported in id at 148; and the simple proportions of pro-civil liberties votes in the fifth through tenth terms, compared with the first and second terms, in cases covered on the front page of the New York Times, reported in Baum and Devins, 98 Georgetown L J at 1577 (cited in note 12). The proportions of pro-civil liberties votes were calculated with use of the Supreme Court Database, described in note 28. Cases were defined as involving civil liberties if they fell within issue areas 1 through 6 in the Database, described at https://perma.cc/6FKS-BRPE.

The adjustment is described in Lawrence Baum, Measuring Policy Change in the U.S. Supreme Court, 82 Am Pol Sci Rev 905 (1988). That adjustment is clearly imperfect, in that it rests on an assumption that the average movement of the Justices between two terms is close to zero. However, it does provide a control for change in the composition of the Court's agenda that causes Justices' voting records to become more liberal or more conservative even if those Justices' actual ideological positions have not changed.

A second complication in tracking the Justices' voting records is that the definition of certain issue positions as conservative or liberal has an element of arbitrariness, because the positions that are considered to be conservative or liberal do not simply follow deductively from broad values. One result is that perceptions of the ideological sides on an issue (such as freedom of expression) sometimes change substantially over time. Lawrence Baum, Ideology in the Supreme Court (Princeton, 2017). The coding of Justices'votes in the Supreme Court Database has been criticized on the ground that it reflects coders' prior expectations about the Justices. Anna Harvey and Michael J. Woodruff, Confirmation Bias in the United States Supreme Court Fudicial Database, $29 \mathrm{~J}$ Law, Econ \& Org 414 (2013). For this reason, data on Justices' voting in table 1 and the tables that follow should be read with caution. At the same time, there is considerable consensus on the ideological direction of the competing positions on most issues, and in the 
several Republican appointees with respect to civil liberties. Table 1 shows those measures for several Republican appointees from Earl Warren through David Souter.

This pattern of leftward movement might be idiosyncratic rather than a reflection of any systematic forces. ${ }^{212}$ But it is a reasonable inference that these Justices, or at least some of them, were influenced by the elite groups with whom they interacted. As we saw in Section II.B, Republican and Democratic elites often favored liberal outcomes on civil liberties issues during this period. ${ }^{213}$ Moreover, legal academia and the most prestigious sector of the mass media leaned to the left in these years. ${ }^{214}$

The impact of social environments seems most evident in the case of Justice Blackmun, whose substantial turn to the left was clearly reinforced by the approval of liberal audiences in the elite news media and other sectors. ${ }^{215}$ Blackmun was unusually attentive to the mail he received relating to his work as a Justice, ${ }^{216}$ and he was close to some reporters. ${ }^{217}$ In public appearances before sympathetic audiences, he solicited and received positive responses to his decisions. ${ }^{218}$

Justice Kennedy also seems particularly concerned with his public persona. According to one of his law clerks, Justice Kennedy "would constantly refer to how it's going to be perceived, how it's going to

short term there is considerable stability in the understanding of which positions are liberal and which positions are conservative.

${ }^{212}$ On the role of chance in creating what appear to be meaningful patterns of behavior, see Carol Mock and Herbert F. Weisberg, Political Innumeracy: Encounters with Coincidence, Improbability, and Chance, 36 Am J Pol Sci 1023 (1992).

${ }^{213}$ See notes $97-100$ and accompanying text.

${ }^{214}$ See notes 110 and 115 and accompanying text; see also Deborah Jones Merritt, Research and Teacbing on Law Faculties: An Empirical Exploration, 73 Chi Kent L Rev 765, 780 n 54 (1998) (discussing left-leaning tendencies of legal academies); Stanley Rothman and S. Robert Lichter, Personality, Ideology, and World View: A Comparison of Media and Business Elites, 15 Brit J Pol Sci 29 (1985) (discussing liberal tendencies of journalists before the Internet age); and David H. Weaver and G. Cleveland Wilhoit, The American Fournalist: A Portrait of U.S. News People and Their Work 25-32 (1991) (discussing the same tendencies).

${ }^{215}$ Baum, fudges and Their Audiences at 153-55 (cited in note 11).

${ }^{216}$ Linda Greenhouse, Becoming fustice Blackmun: Harry Blackmun's Supreme Court Fourney 134, 242 (Times Books, 2005); Harold Hongju Koh, A Tribute to Fustice Harry A. Blackmun, 108 Harv L Rev 20, 20 (1994).

${ }^{217}$ Richard Davis, Decisions and Images: The Supreme Court and the Press 106 (1994).

${ }^{218}$ Neil A. Lewis, Blackmun on Search for the Center, NY Times, A7 (Mar 8, 1986); Reynolds Holding, Blackmun Says Court Direction Disappointing, SF Chron, A12 (June 10, 1992). 
Table 1

Change in Percentages of Liberal Votes in Civil Liberties Cases, Selected Republican Appointees, 1st-2nd Terms to 5th-10th Terms (Part 1)"

\begin{tabular}{lccr}
\hline Justice & All Votes & $\begin{array}{c}\text { All Votes, } \\
\text { Adjusted }\end{array}$ & $\begin{array}{c}\text { Important } \\
\text { Cases }^{c}\end{array}$ \\
\hline Earl Warren & +34.8 & +38.9 & +16.6 \\
Potter Stewart & +13.0 & +12.5 & +6.6 \\
Harry Blackmun & +6.9 & +9.6 & +15.1 \\
Lewis Powell & +2.2 & +7.9 & +12.0 \\
John Paul Stevens & +1.6 & +4.4 & +6.7 \\
Sandra Day O'Connor & +1.4 & -3.0 & +14.3 \\
Anthony Kennedy & +13.9 & +1.6 & +33.7 \\
David Souter & +24.9 & +25.7 & +20.4 \\
\hline
\end{tabular}

a Scores on the first two measures are taken from Baum, Fulges and Their Audiences at 147-48 (cited in note 11); scores on the third measure are taken from Baum and Devins, 98 Georgetown L J at 1577 (cited in note 12).

${ }^{\mathrm{b}}$ On this adjustment, see note 211 .

c Cases are defined as important if the Court's decisions were reported the following day on the front page of the New York Times. This measure of case importance is described and examined in Epstein and Segal, 44 Am J Pol Sci (cited in note 36).

look." ${ }^{219}$ On the day the Court reaffirmed Roe in Planned Parenthoodv Casey, ${ }^{220}$ he told a reporter that "[s]ometimes you don't know if you're Caesar about to cross the Rubicon or Captain Queeg cutting your own tow line." 221

By the time of Casey, however, the dominance of left-leaning media and academic elites had begun to wane. Conservative media outlets started to permeate the American mainstream, ${ }^{222}$ the conservative legal network was on the rise, and the very incentives that had once pushed Republican nominees to the left now pushed a new breed of Republican nominees to the right.

\section{REPUBLICAN APPOINTEES: THE CURRENT COURT}

Aside from Justice Kennedy, the Republicans on the Roberts Court have remained steadfast in their conservatism: Justice Scalia

\footnotetext{
${ }^{219}$ Jeffrey Rosen, The Agonizer, New Yorker (Nov 11, 1996), 82, 86 (quoting an unnamed Supreme Court clerk).

${ }^{220}$ Planned Parenthood v Casey, 505 US 833 (1992).

221 Terry Carter, Crossing the Rubicon, Cal Lawyer 39, 39-40 (quoting Justice Kennedy).

${ }^{222}$ Grossman and Hopkins, Asymmetric Politics at 150 (cited in note 77).
} 
Table 2

Change in Percentages of Liberal Votes in Civil Liberties Cases, Selected Republican Appointees, 1st-2nd Terms to 5th-10th Terms (Part 2)

\begin{tabular}{lccc}
\hline Justice & All Votes & $\begin{array}{c}\text { All Votes, } \\
\text { Adjusted }\end{array}$ & $\begin{array}{c}\text { Important } \\
\text { Cases }\end{array}$ \\
\hline Warren Burger & -4.4 & -9.7 & -10.0 \\
William Rehnquist & -4.6 & +2.1 & -3.0 \\
Antonin Scalia & -3.3 & -16.1 & -9.7 \\
Clarence Thomas & -3.9 & -3.3 & -20.6 \\
John Roberts & +13.2 & +8.5 & - \\
Samuel Alito & +5.2 & +1.0 & - \\
\hline
\end{tabular}

a See notes to table 1 . No results are shown for important cases for Roberts and Alito because the list on which that analysis is based has not been updated since 2010 .

served for close to thirty years before his death, Justice Thomas has served for more than twenty-five years, and Justice Alito and Chief Justice Roberts have served for more than a decade. ${ }^{223}$ As table 2 shows, only Roberts has moved in a liberal direction by the measures reflected in the table. Table 3 details the proportions of liberal and conservative votes by the conservative Justices-showing both fluctuations over time and the substantial gap between all four of the strong conservatives and Justice Breyer, the most moderate of the Court's liberals. ${ }^{224}$ Because voting records are affected by changes in the Court's agenda from term to term, a Justice's record relative to the records of her colleagues in each pair of terms provides a better sense of her ideological positions than do changes in her proportions of liberal and conservative votes over time. ${ }^{225}$

The primary reason for the difference between the voting behavior of these Republican appointees and several of their predecessors is the evolution of appointment strategies discussed earlier. ${ }^{226}$ In Sec-

\footnotetext{
${ }^{223}$ This, of course, is not to suggest that conservative Justices vote as a bloc, consistently supporting conservative outcomes. There are important deviations, but these Justices generally back conservative outcomes.

${ }^{224}$ And while change in the Court's civil liberties agenda has resulted in some upward movement in their support for parties with civil liberties claims, the Court's four strong conservatives were relatively unfavorable to such claims - though with some important exceptions - throughout the 2005-15 Terms.

${ }^{225}$ See notes $210-11$ and accompanying text.

${ }^{226}$ See Section III.B.
} 
Table 3

Proportions of Liberal Votes in Civil Liberties Cases, Roberts Court, Selected Justices (Part 1)

\begin{tabular}{lccccc}
\hline & \multicolumn{5}{c}{ Justice } \\
\cline { 2 - 6 } Terms $^{1}$ & Scalia & Thomas & Roberts & Alito & Breyer \\
\hline $2005-06$ & 23.9 & 19.7 & 23.5 & 19.6 & 63.4 \\
$2007-08$ & 27.9 & 18.6 & 31.4 & 26.7 & 61.2 \\
$2009-10$ & 44.4 & 34.6 & 43.2 & 30.4 & 56.8 \\
$2011-12$ & 32.9 & 25.0 & 32.9 & 21.3 & 53.9 \\
$2013-15$ & 37.0 & 32.7 & 48.5 & 34.7 & 64.0 \\
\hline
\end{tabular}

"Each entry refers to a pair of terms or, for 2013-15, three terms. Thus, "2005-06," for instance, includes the 2005 and 2006 Terms of the Court.

tion III.B, we explored the role of ideology in these appointments ${ }^{227}$ and explained that these four appointees have social identities that are deeply rooted in the conservative legal movement. ${ }^{228}$

Once these Justices joined the Court, the conservative movement continued to serve as an important reference group for them. Unlike earlier periods (when elite social networks were dominated by liberals), conservative Justices on the Roberts Court had links with likeminded groups and individuals who supported and reinforced their conservative positions. In particular, as noted in Section II.B, changes in the news media, academia, and the legal profession led to the establishment of conservative elite social networks. ${ }^{229}$

In the case of Justice Thomas, ${ }^{230}$ for example, the elite conservative sector provided personal support during his early years on the Court, when he felt beleaguered by the criticism he had received during his highly contentious confirmation hearings. In response, in the words of one reporter, Thomas "constructed a world apart from his critics." ${ }^{231}$ He has appeared at law schools with relatively con-

\footnotetext{
${ }^{227}$ See notes 160-93 and accompanying text.

${ }^{228}$ See notes 170-94 and accompanying text (noting ties of these nominees to conservative movement); notes 185-90 and accompanying text (discussing disavowal of Miers by conservative legal movement).

${ }^{229}$ See notes 111-21 and accompanying text.

${ }^{230}$ This paragraph draws from Baum, Fudges and Their Audiences at 132-35 (cited in note 11).

${ }^{231}$ Marc Fisher, The Private World of Justice Thomas, Wash Post at B1 (Sept 11, 1995).
} 
servative orientations ${ }^{232}$ and focused his attention on news media with a similar point of view. ${ }^{233} \mathrm{He}$ has maintained ties with conservative leaders and organizations like the Federalist Society, ${ }^{234}$ and he has acknowledged that conservatives in the legal community serve as an important reference group for him. ${ }^{235}$ It is noteworthy that when Thomas returned to Yale Law School in 2011, the two student groups with which he met were the Black Law Students Association and the law school's chapter of the Federalist Society. ${ }^{236}$

As an original leader of the Federalist Society, ${ }^{237}$ Justice Scalia already had deep roots in the conservative segment of the legal elite by the time he became a Justice. Over the years, he made frequent appearances before groups with a conservative orientation. He was regularly honored by the Federalist Society ${ }^{238}$ and participated frequently in the organization's events. In 2012 alone Scalia participated in at least five Federalist Society events. ${ }^{239}$ In 2013 he traveled to Montana to speak at a lunch aimed at building support for creation of a state chapter of the society, ${ }^{240}$ and in 2014 he journeyed to New York City to give a speech before a Federalist Society group. ${ }^{241}$

${ }^{232}$ As a few examples, Justice Thomas has recently appeared at Duke, see Duke Law School, Fustice Clarence Thomas Shares His fourney from the South to the Supreme Court (Oct 25, 2013), archived at https://perma.cc/EKY3-ETAA, and Harvard, see Harvard Law School, Fustice Thomas Speaks at Harvard Law (video) (Feb 11, 2013), archived at https://perma.cc /WKV3-LV47, and UVA, see University of Virginia School of Law, U.S. Supreme Court Justice Thomas Visits UVA Law School (Mar 13, 2012), archived at https://perma.cc/KBW9 $-\mathrm{XX} 2 \mathrm{~N}$.

${ }^{233}$ Lee Roderick, Leading the Charge: Orrin Hatch and 20 Years of America 369-70 (Gold Leaf, 1994).

${ }^{234}$ Baum, Fudges and Their Audiences at 133-34 (cited in note 11).

${ }^{235}$ Clarence Thomas, Address Before the Federalist Society at the 1999 National Lawyers Convention (Nov 12, 1999), archived at https://perma.cc/9TWX-PU9D.

${ }^{236}$ Yale Law School, Fustice Clarence Thomas '74 Visits the Law School; Meets with Student Groups, Teaches Class (Dec 14, 2011), archived at https://perma.cc/QU7X-TYXP.

${ }^{237}$ Teles, Conservative Legal Movement at 141-42 (cited in note 13); Joan Biskupic, American Original: The Life and Constitution of Supreme Court fustice Antonin Scalia 5 (Farrar, Straus and Giroux, 2009).

${ }^{238}$ Biskupic, American Original at 7 (cited in note 237).

${ }^{239}$ Antonin Scalia, Financial Disclosure Report for Calendar Year 2012, 3 (May 15, 2013), archived at https://perma.cc/PJL6-E7R4. The financial disclosure reports indicate reimbursed travel, so they do not include appearances in Washington, D.C.

${ }^{240}$ Laura Lundquist, Supreme Court Fustice Is Draw for Conservative Luncheon, Bozeman Chron (Aug 19, 2013), archived at https://perma.cc/VR5D-6M2R.

${ }^{241}$ Antonin Scalia, Financial Disclasure Report for Calendar Year 2014, 3 (May 15, 2015), archived at https://perma.cc/N79M-USF3. 
Among his other appearances that year was a speech before a group of Hollywood conservatives called the "Friends of Abe." ${ }^{242}$ In 2011, he spoke to members of Congress about constitutional interpretation at an event organized by the Tea Party Caucus. ${ }^{243}$

As a judge on a federal court of appeals, Samuel Alito was "particularly active at Federalist Society national meetings." $244 \mathrm{He}$ was strongly backed by conservative groups at the time of his nomination to the Supreme Court ${ }^{245}$ and he has maintained his ties with conservative groups in the years since. Between 2010 and 2012, he appeared at three meetings of the Federalist Society outside Washington, D.C. and at the conservative Manhattan Institute. ${ }^{246}$ In 2008, Alito was the keynote speaker at the annual dinner for the conservative magazine the American Spectator, and his remarks included distinctly partisan content. He also appeared at the magazine's annual dinner in $2010 .^{247}$ At a 2012 Federalist Society dinner, Alito took aim at both the Obama administration and critics of Citizens United, charging that critics of the decision were misleading the public and that the Obama Department of Justice was advancing a vision of society in which the "federal government towers over the people."248 In 2014, Alito was again the featured speaker at the Federalist Society's annual dinner. ${ }^{249}$ In 2016 Alito spoke at the society's annual meeting for lawyers, as did Justice Thomas. Alito described what

${ }^{242}$ Id. On the Friends of Abe, see Amy Fagan, Hollywood's Conservative Underground, Wash Times A1 (July 23, 2008).

${ }^{243}$ Bill Mears, Fustice Salia Set to Address Tea Party Caucus on Capitol Hill, CNN.com (Jan 21, 2011), archived at https://perma.cc/LK7W-ZQTA.

${ }^{24+}$ Tushnet, $I n$ the Balance at 49 (cited in note 21).

${ }^{245}$ See note (discussing Alito's support from conservative groups).

${ }^{246}$ Samuel A. Alito, Financial Disclosure Report for Calendar Year 2010, 3 (May 12, 2011), archived at https://perma.cc/UN8S-ERNC; Samuel A. Alito, Finamial Disclostre Report for Calendar Year 2011, 2-3 (Aug 13, 2012), archived at https://perma.cc/X932-ZALF. The Manhattan Institute for Public Policy describes its mission and activities at https://perma.cc/5R7M -KQ8R.

${ }^{247}$ Jeff Shesol, Should Fustices Keep Their Opinions to Themselves?, NY Times A23 (June 29, 2011). The 2010 appearance featured a confrontation with a liberal blogger who challenged Alito's involvement in a fundraising dinner. Debra Cassens Weiss, Blogger Loudly Questions Alito's Dinner Attendance, Tapes Irate Security Guard, ABA J (Nov 11, 2010), archived at https://perma.cc/MGQ3-Z9PT.

${ }^{248}$ See Mark Sherman, Samuel Alito, Supreme Court fustice, Takes on Citizens United Critics, Huffington Post (Nov 17, 2012), archived at https://perma.cc/9LNE-9R6B.

${ }^{249}$ Shortly after that Federalist Society appearance, Linda Greenhouse wrote that Alito has a "base" in the conservative movement. Linda Greenhouse, It's All Right with Sam, NY Times (Jan 7, 2015), archived at https://perma.cc/F9TK-PBSK. 
one publication called a "conservative agenda" for the Court. ${ }^{250}$ For his part, Thomas referred to his friendship with Justice Scalia as a "band of brothers," and he urged his audience "to join this band of brothers." 251

Chief Justice Roberts's record is more ambiguous than that of the Court's other conservatives. ${ }^{252}$ On the whole, however, Roberts is clearly a conservative. ${ }^{253}$ As table 3 shows, his record is much more conservative than that of Justice Breyer, the most moderate of the Court's liberal Justices. ${ }^{254}$ Roberts's voting record is best explained by a more moderate set of conservative policy preferences and his strategic considerations as Chief Justice. ${ }^{25}$ Although his ties to the conservative movement since he joined the judiciary have not been as dramatic as those of Alito, Scalia, and Thomas, he participated in the twenty-fifth anniversary celebration of the Federalist Society in

${ }^{250}$ Lawrence Hurley, Alito Outlines Possible Conservative Agenda for U.S. High Court, Reuters (Nov 17, 2016), http://www.reuters.com/article/us-usa-court-alito-idUSKBN13C2E7.

251 Tony Mauro, Fustice Thomas to Fed Society: Scalia's Work Is "Prologue," Nat'l L J (Nov 18, 2016), hitp://www.nationallawjournal.com/id = 1202772781445/Justice-'Thomas-to-Fed-So ciety-Scalias-Work-Is-Prologue? slreturn $=20161025123108$.

${ }^{252}$ In one of the debates among the candidates for the 2016 Republican nomination for president, Ted Cruz referred to his support for Roberts's confirmation in 2005 as "a mistake," and even Jeb Bush hedged in his approval of his brother's nomination of Roberts. CNN Reagan Library Debate: Later Debate Full Transcript, CNN.com (Sept 16, 2015), archived at https://perma.cc/G78M-25UA. Donald Trump also attacked Roberts for writing an opinion catering to those inside the "beltway." See Egelko, Trump, Rubio Weigh in on Supreme Court Abead of Debate (cited in note 5).

${ }^{253}$ Adam Liptak, Chief Zustice Amasses a Conservative Record, and Wratb from the Right, NY Times A16 (Sept 29, 2015).

${ }^{254}$ Roberts's Martin-Quinn scores also highlight his relative conservativism, as does an ideological ranking devised by Judge Richard Posner and William Landes. See note 70 and accompanying text. Roberts's relatively high proportions of liberal votes in the 2013 and 2014 Terms, like the Court's relatively high proportions of liberal decisions in those terms, probably reflect the kinds of cases that the Court heard in those terms. See Brendan Nyhan, Supreme Court: Liberal Draft v. Conservative Overreach, NY Times (June 25, 2015), archived at https://perma.cc/E8GR-CQCX. See also Kevin T. McGuire et al, Measuring Policy Content on the U.S. Supreme Court, 71 J Pol 1305 (2009) (explaining how case selection skews ideological ranking of Justices by making courts appear more liberal or conservative).

${ }^{255}$ See Dan Balz, Roberts Health Care Ruling Sends a Message to Politicians, Wash Post (June 30, 2012), archived at https://perma.cc/6AQ'T-8RCF (discussing institutional concerns in Roberts ruling); Adam Liptak, Angering Conservatives and Liberals, Cbief Fustice Roberts Defends Steady Restraint, NY Times (June 26, 2015), archived at https://perma.cc/Z78CYGX2 (discussing ways Roberts trades off ideology for the pursuit of institutional goals). For a general treatment of how institutional concerns, including the power to assign decisions, shape the decision making of Chief Justice Roberts, see Richard J. Lazarus, Back to Business at the Supreme Court: The Administrative Side of Chief Zustice Roberts, 129 Harv L Rev F 33 (Nov 9, 2015), archived at https://perma.cc/7VL9-2U6S. 
$2007^{256}$ and, following Justice Scalia's lead, he presented a featured lecture at the society's annual meeting that same year. ${ }^{257}$

Another measure of the allegiance of today's Republican-appointed Justices to the conservative legal network is their tendency to hire law clerks who share their ideological views. ${ }^{258}$ Justices gave some weight to ideology in their selection of law clerks even before party polarization took hold, but that weight was limited. Reflecting the dominant ideology of the time, law clerks in that earlier era tended to be left-leaning, even if their Justice was not. ${ }^{259}$ That is no longer true. Today, as measured by the lower-court judges from whom the Justices draw their clerks, the tendency of Justices to take ideology into account has become markedly stronger since the early 1990 s, especially among conservative Justices. ${ }^{260}$ 'Table 4 shows the Justices' hiring practices for the 2005-16 Terms, the first twelve terms of the Roberts Court. The differences between conservative and liberal Justices shown in table 4 are far greater than those that existed in the late $1970 \mathrm{~s}$ and early 1980 s. ${ }^{261}$

\footnotetext{
${ }^{256}$ Robert Barnes, Federalists Relish Well-Placed Friends: President, Several fustices Help Celebrate Legal Society's 25 Years of Conservatism, Wash Post A3 (Nov 16, 2007). Justice Thomas participated prominently in the 2013 annual convention of the Federalist Society, and Justices Scalia and Alito attended the convention. Ian Millhiser, How Conservatives Abandoned Fudicial Restraint, Took Over the Courts and Radically Transformed America, ThinkProgress (Nov 19, 2013), archived at https://perma.cc/MP2Y-SJBD.

${ }^{257} 7$ th Annual Barbara K. Olson Memorial Lecture, The Federalist Society (Nov 16, 2007), archived at https://perma.cc/7P2P-WNKH.

${ }^{258}$ Artemus Ward and Davis L. Weiden, Sorcerers' Apprentices: 100 Years of Law Clerks at the United States Supreme Court (New York University, 2006). Since the 1970s, when it became standard practice for Justices to select clerks who had served in lower courts, there has been a similar tendency for Justices to take clerks from judges on the same side of the ideological spectrum. See id at 83-84.

${ }^{259}$ Todd C. Peppers, Courtiers of the Marble Palace: The Rise and Influence of the Supreme Court Law Clerk 34-37 (Stanford Law and Politics, 2006).

${ }^{260}$ Corey Ditslear and Lawrence Baum, Selection of Law Clerks and Polarization in the U.S. Supreme Court, 63 J Pol 169 (2001); Lawrence Baum, Hiring Supreme Court Law Clerks: Probing the Ideological Linkage Between fudges and fustices, 98 Marq L Rev 333 (2014). See also Nelson et al, 62 Vand L Rev at 1775-80 (cited in note 121); Adam Liptak, $A$ Sign of Court's Polarization: Choice of Clerks, NY Times A1 (Sept 7, 2010); Geoffrey R. Stone, The Difference Between Conservative and Liberal fustices, Huffington Post (Nov 2, 2013), archived at https:// perma.cc/PTP5-RB39. As in the past, at least some Justices also take the ideological positions of prospective clerks themselves into account. Amy Bach, Movin' on Up with the Federalist Society: How the Right Rears Its Young Lanvyers, Nation 11, 15 (Oct 1, 2001).

${ }^{261}$ In the 1975-80 Terms, the highest percentage of clerks drawn from Democraticappointed judges was 68.2 (for Justice Marshall); the lowest proportion was 37.5 (for Justice Rehnquist). In the 1981-85 Terms, the highest proportion was 73.7 (for Justice Brennan); the lowest was 40.0 (for Rehnquist and Chief Justice Burger). Ditslear and Baum, $63 \mathrm{~J} \mathrm{Pol} \mathrm{at} 880$ (cited in note 260). It is also noteworthy that clerks working for or slotted to work for Justice
} 
Table 4

Proportion of Justices' Law Clerks Who Had

Previously Served with a Republican-Appointed

Lower-Court Judge, 2005-16 Terms ${ }^{2}$

\begin{tabular}{lc}
\hline Justice & Percentage \\
\hline Thomas & 97.9 \\
Scalia & 97.7 \\
Alito & 94.4 \\
Roberts & 80.9 \\
Kennedy & 79.2 \\
Breyer & 40.4 \\
Stevens & 40.0 \\
Sotomayor & 37.5 \\
Kagan & 32.1 \\
Souter & 25.0 \\
Ginsburg & 23.4 \\
\hline
\end{tabular}

"These percentages were calculated from the information sheets compiled by the Court each term, Law Clerks-October Term [various years]: Law Schools and Prior Clerksbips; for the 2016 term, the information is from David Lat, Supreme Court Clerk Hiring Watch: The Official List, Above the Law (July 22, 2016), abovethelaw.com/2016/07/supreme-court-clerk-hiring-watch -the-official-list-for-ot-2016/. Clerks who served with state judges or with the future Justice on a lower court and those who had no prior clerkships are not included. Where a clerk had multiple prior clerkships, the most recent clerkship was used; when the most recent clerkship could not be ascertained, a clerkship in a court of appeals was counted rather than one in a district court.

Unlike the 1950s through the 1990s, there is no longer a leftward pull on Republican appointees. Justices whose social identities were linked with conservatives and conservative groups prior to their appointments can now gain enthusiastic approval from conservative elites. Moreover, as demonstrated by their reactions to the 2012 and 2015 health care decisions and the 2015 decision on same-sex mar-

\footnotetext{
Antonin Scalia found homes with Republican Justices after Scalia's death. Scalia's 2015 Term clerks completed their clerkships with Justices Alito and Thomas; clerks hired by Scalia for the 2016 Term found positions with Justices Thomas, Alito, and Kennedy. Tony Mauro, Future Scalia Clerks Find New Homes with Other Fustices, Natl L J (May 13, 2016), at http:// www.nationallawjournal.com/id $=1202757606269 /$ Future-Scalia-Clerks-Find-New-Homes -With-Other-Justices; David Lat, Supreme Court Hiring Watch, Above the Law (July 28, 2016), at http://abovethelaw.com/2016/07/supreme-court-clerk-hiring-watch-a-look-at-october-term $-2017 \%$.
} 
riage, conservative elites will sharply condemn any deviations from their own positions. ${ }^{262}$

\section{DEMOCRATIC APPOINTEES}

The increasing ideological distance between Democratic- and Republican-appointed Justices is largely a story of changes in the Republican Party. As a group, the Republican-appointed Justices have been appreciably more conservative than previous Republican nominees. ${ }^{263}$ For their part, Democratic-appointed Justices are more homogeneous than before, but as a group they are not more liberal. Unlike previous Democratic appointees (some of whom were very liberal and others of whom were either moderate or conservative), all of today's Democratic-appointed Justices are moderate liberals. ${ }^{264}$ As noted in Part III, the ideology of Supreme Court nominees has been more important to recent Republican presidents than to recent Democratic presidents.

The changing profile of Democratic nominees is tied to broader changes in the Democratic Party. Before the mid-1960s, the Democratic Party reflected an uneasy alliance between northern liberals and southern conservatives. ${ }^{26.5}$ The ideologically mixed character of the Democratic Party at that time was reflected in Supreme Court nominations. In a later era, nominees who held views like those of Stanley Reed, Fred Vinson, Sherman Minton, and Tom Clark would have been Republicans rather than Democrats; perhaps the same is

${ }^{262}$ The decisions were, respectively, National Federation of Independent Business $v$ Sebelius (note 22); King $v$ Burwell (note 22); and Obergefell $v$ Hodges (note 209). Examples of conservatives' responses to Justice Kennedy's decisive vote on Obergefell are Daniel Horowitz, 7ustice Kennedy's Naked Politics and the Hypocrisy of the Court, Conservative Review, July 6, 2015, at https://www.conservativereview.com/commentary/2015/07/Justice-kennendys-naked-politics -and-the-hypocrisy-of-the-court; and S. Ernie Walton, Conservatives Should Attack Obergefell's Interpretive Metbod, Not Its Hijacking of the Democratic Process, September 26, 2015, at https:// papers.ssrn.com/sol3/papers.cfm?abstract_id $=2667223$. For conservative elite reaction to Chief Justice Roberts's votes in the Affordable Care Act decisions, see Adam Liptak, Chief Fustice fobn Roberts Amasses a Conservative Record, and Wrath from the Right, NY Times (Sept 28, 2015), at http://www.nytimes.com/2015/09/29/us/politics/chief-Justice-john-roberts-amasses-conservative -record-and-the-rights-ire.html?_r=0; David G. Savage, Chief Fustice Roberts' Recorl Isn't Conservative Enough for Some Activists, LA Times (Sept 25, 2015), at http://www.latimes.com/nation /a-na-roberts-conservative-backlash-20150924-story.huml.

${ }^{263}$ See notes 69-70.

${ }^{264}$ See figure 1 and accompanying text. See note 152 and accompanying text.

${ }^{265}$ See Richard H. Pildes, Why the Center Does Not Hold: The Canses of Hyperpolarized Democracy in America, 99 Cal L Rev 273, 290 (2011). 
true of Byron White. ${ }^{266}$ Nor was there anything like a liberal legal establishment in that era. The leaders of the American Bar Association, for instance, tended to be relatively conservative until the $1960 \mathrm{~s}^{267}$

Steven Teles has described how this changed with the development of what he calls "the liberal legal network."268 Following the social changes of the 1960s, the American Civil Liberties Union and the NAACP Legal Defense and Education Fund were joined by a set of new liberal public interest law firms. Legal academia took on a more liberal cast. Elite institutions, including the American Bar Association, also embraced more liberal positions. The civil libertarianism of the late Warren Court both reflected and contributed to these changes. The result was the creation of a liberal network in the elite segment of the legal profession, although that network was looser and more diverse in its thinking than the conservative network that developed later. ${ }^{269}$

The changes of the 1960s extended beyond the legal profession. The elite news media became more liberal, as did the "WashingtonGeorgetown social set" to which President Nixon referred. ${ }^{270}$ The leftward shift of the Democratic Party in the 1960s and 1970s helped ensure that when Democratic presidents once again gained an opportunity to appoint Justices (beginning with Clinton in 1993), they would choose people who were at least moderately liberal. At the same time, the development of a liberal legal network created an elite audience for the Justices who supported liberal policy positions. Because there was no competing conservative legal network at that time, the growing liberalism of the elite world reinforced the liberalism of Democratic judicial appointees.

Since roughly 2000, the success of conservative legal organizations in shaping law and policy has made liberals more aware of the impact of elite networks. In particular, liberal lawyers and law professors perceived a need for an organization that would serve as a counter-

\footnotetext{
${ }^{266}$ See note 136 (discussing relative conservativism of the Truman nominees).

${ }^{267}$ Teles, Conservative Legal Movement at 28-29 (cited in note 13).

${ }^{268} \mathrm{Id}$ at $22-57$.

${ }^{269}$ David Fontana, How Size Matters for Liberal and Conservative Constitutionalism (unpublished manuscript) (on file with authors).

${ }^{270}$ See note 206.
} 
weight to the Federalist Society. ${ }^{271}$ The American Constitution Society (ACS), founded in 2001, is largely parallel to the Federalist Society in its activities and goals. ${ }^{272}$ At the same time, though, no one group dominates the liberal legal network, and ideology plays a less overt role in Democratic appointments. ${ }^{273}$ The lack of dominance for a single group reflects the multiplicity of organizations with a liberal orientation that have an interest in judicial appointments and policies. $^{274}$

Nonetheless, Democratic-appointed Justices undoubtedly see themselves as members of a different team than their Republican counterparts. ${ }^{275}$ The ACS accentuates and facilitates this divide. Justices Breyer, Ginsburg, and Sotomayor have all been keynote speakers at the ACS national convention. ${ }^{276}$ In greeting a national student convention of the Federalist Society in 2005 when she was dean of the Harvard Law School, Elena Kagan declared that "I love the Federalist Society," but "You are not my people." 277 Moreover, all of the Democratic-appointed Justices in recent years have tended to appoint law clerks who have served with judges nominated by Democratic presidents, although the strength of that inclination varies considerably and is dwarfed by the tendency of the Republican-appointed Justices to rely on Republican-appointed lower court judges. ${ }^{278}$

${ }^{271}$ Crystal Nix Hines, Young Liberal Law Group Is Expanding, NY Times A17 (June 1, 2001).

${ }^{272}$ Alexander Wohl, Liberalizing the Lawv, The Nation 6 (June 16, 2003); Carol D. Leonnig, Dancing? It's Good for the Constitution: Fanet Reno and Friends Try an Unconservative Approach, Wash Post C1 (Aug 4, 2003); Tresa Baldas, Law School Turf War Ignites, Natl L J 1, 12 (Apr 26, 2004).

${ }^{273}$ See notes 143-52 and accompanying text.

${ }^{274}$ See Fontana, How Size Matters (cited in note 269).

${ }^{275}$ See notes 101-09.

${ }^{276}$ Most recently, Ginsburg was the keynote speaker in 2015 and Sotomayor in 2014. See Adam Liptak, Fustices Get Out More, but Calendars Aren't Open to fust Anyone, NY 'Times (June 1, 2015), archived at https://perma.cc/M9JM-6NTA. Breyer was also keynote speaker at the banquet of the ACS national conference in 2004, see Fustice Stephen Breyer at the 2004 Annual Convention, American Constitution Society (July 25, 2005), archived at https://perma .cc/WGD9-9RP4, and Ginsburg spoke at the first national conference in 2003, "because the Society's mission is important to the health and welfare of our Nation," see Ruth Bader Ginsburg, Associate Justice, Supreme Court of the United States, Remarks for the American Constitution Society: Looking Beyond Our Borders: The Value of a Comparative Perspective in Constitutional Adjudication 1 (Aug 2, 2003), archived at https://perma.cc/UA8P-UNUG.

${ }^{277}$ Tushnet, A Court Divided: The Rehnquist Court and the Future of Constitutional Law 90 (Norton, 2005).

${ }^{278}$ See table 4. 
Table 5

Percentage of Liberal Votes in Civil Liberties Cases, Roberts Court, Selected Justices (Part 2)

\begin{tabular}{lcccccc}
\hline & \multicolumn{5}{c}{ Justice } \\
\cline { 2 - 7 } Terms & Ginsburg & Breyer & Sotomayor & Kagan $^{2}$ & Kennedy & Alito \\
\hline $2005-06$ & 66.2 & 63.4 & - & - & 35.2 & 19.6 \\
$2007-08$ & 69.8 & 61.2 & - & - & 39.5 & 26.7 \\
$2009-10$ & 60.5 & 56.8 & 63.8 & 64.3 & 46.9 & 30.4 \\
$2011-12$ & 68.4 & 53.9 & 66.7 & 67.6 & 46.7 & 21.3 \\
$2013-15$ & 63.4 & 64.0 & 71.0 & 62.6 & 50.5 & 34.7 \\
\hline
\end{tabular}

"Kagan, whose tenure began with the 2010 Term, participated in only twenty-eight civil liberties decisions in that term.

Table 5 provides some perspective on the ideological positions of the current Court's Democratic appointees. All have been distinctly to the left of even the most liberal Republican-appointed Justice, Anthony Kennedy. The gap between them and the four more strongly conservative Republican-appointed Justices (represented in table 5 by Justice Alito) is even more substantial.

The convictions of Democratic-appointed Justices are undoubtedly strengthened by liberal elite networks. These networks still dominate the academy, lawyer groups, and much of the media. ${ }^{279}$ As this part makes clear, the fact that there are substantial audiences on both the liberal and conservative sides reduces the possibility that Republican or Democratic appointees will move away from their parties' predominant positions during their tenure on the Court.

\section{Conclusions}

In the period that ended with Clarence Thomas's appointment to the Supreme Court in 1991, the role of the president's party affiliation in shaping the Court's ideology was surprisingly small by current standards. Republicans often appointed moderates and liberals; Democrats often appointed moderates and conservatives.

\footnotetext{
${ }^{279}$ See John O. McGinnis et al, The Patterns and Implications of Political Contributions by Elite Law Faculty, 93 Georgetown L J 1167 (2005) (noting the propensity of law professors to contribute to Democrats); Adam Bonica, Adam S. Chilton, and Maya Sen, The Political Ideologies of American Lawyers, J Legal Analysis (forthcoming), archived at https://perma.cc /URQ8-QWWL (asserting that law professors are at least as liberal as any other cohort of lawyers, including public defenders).
} 
One vivid reflection of that pattern is evident in the frustration of conservatives with the failure of the Burger and Rehnquist Courts to turn as far to the right as they had hoped for after a string of eight consecutive Republican appointments to the Court. ${ }^{280}$

Things have changed, though. Starting with the Reagan administration, presidents have increasingly paid attention to ideology in Supreme Court appointments. Republicans, in particular, helped establish a conservative legal network to vet and groom candidates for judicial appointment. And following the retirements of moderate Republican-appointed Justices David Souter in 2009 and John Paul Stevens in 2010, the lines of ideological division on the Court have, for the first time, coincided with partisan division. Today, every Justice appointed by a Democratic president stands to the left of every Justice appointed by a Republican president, and this is not likely to change any time soon.

This development reflects fundamental changes in American politics. The growing ideological polarization of the parties at the elite level has given presidents stronger incentives to choose nominees whose ideological orientations match those of the president's own party. Elite polarization has also spurred the development of rival liberal and conservative social networks, and those networks have enhanced the president's ability to reliably identify predictably liberal or conservative nominees. Partisan polarization has affected the Justices as well, reducing the likelihood that they will stray from the ideological positions that brought them to the Court in the first place.

The most direct consequence of this change is that presidential elections mean even more for the direction of the Supreme Court than they did in the past. The sudden death of Antonin Scalia and the ensuing imbroglio over the nomination of Merrick Garland underscore this realty. More generally, although the timing of vacancies on the Court is usually uncertain, it has become more certain how presidents will fill them. ${ }^{281}$ Because Justices today typically serve for

\footnotetext{
${ }^{280}$ See Vincent Blasi, ed, The Burger Court: The Counter-Revolution That Wasn't (1986); Craig Bradley, ed, The Rebnquist Legacy (Oxford, 2006); Robert F, Nagel, Bowing to Precedent, Weekly Standard (Apr 17, 2006), archived at https://perma.cc/MTY7-AKNN (noting failure of Rehnquist Court to overrule precedents on school prayer, abortion, and other divisive issues).

${ }^{281}$ We do not mean to suggest that a Republican president will never again appoint a liberal Justice or that a Democrat will never appoint a moderate or conservative Justice. Our point is that party polarization makes such an appointment unlikely.
} 
longer periods than the Justices of earlier eras, ${ }^{282}$ the impact of presidential elections on the Court's membership comes more slowly than in the past. But that impact is now more long-lasting.

Further, as the Court's Republican- and Democratic-appointed Justices become more distant from each other ideologically, the Court's policy direction will become more volatile. In times when the number of Justices appointed by presidents of each party is close to equal, a single appointment can produce a substantial shift in the balance on the Court and, thus, in its decisions. By the same token, it will be less common for a single Justice to play the role of a moderate who stands between the Court's conservative and liberal sides. Anthony Kennedy plays that role to some degree on today's Court. ${ }^{283}$ No other Justice comes close to crossing party lines as frequently, and we doubt that future appointees will play such a role anytime soon.

The Senate Republicans' refusal to confirm Merrick Garland, combined with the election of Donald Trump in 2016, will have a profound impact on the balance and direction of the Court. As a candidate, Trump made clear his goal of appointing Justices who would take conservative positions on specific issues, ${ }^{284}$ and the candidates on his lists of potential nominees are all strong conservatives. ${ }^{285}$ Thus, if any of the three most senior Justices (Ginsburg, Kennedy, and Breyer) leaves the Court in the next four years, we can expect to see a sharp turn to the right, even relative to the Court before Justice Scalia's death. No longer will Anthony Kennedy be the "swing vote." Instead, it will likely be Chief Justice Roberts. ${ }^{286}$ In that event, the Court will even more strongly reflect the partisan divide that is the central attribute of government and politics today. And presidential elections will matter more to the Supreme Court's decision making going forward than they have ever mattered in our nation's history.

On January 31, 2016, President Donald Trump nominated Judge Neil Gorsuch to fill the vacancy on the Supreme Court; on April 7, 2017, the Senate confirmed the nomination. The choice of Gorsuch

${ }^{282}$ Justin Crowe and Christopher F. Karpowitz, Where Have You Gone, Sherman Minton? The Decline of the Short-Term Supreme Court fustice, 5 Persp on Pol 425 (2007).

${ }^{283}$ See table 5; see also Epstein and Jacobi, 61 Stan L Rev (cited in note 27).

${ }^{28+}$ See note 5 .

${ }^{285}$ See note 192 and accompanying text.

${ }^{286}$ See Wolf, Aging Supreme Court Energizes Republicans More Than Democrats (cited in note 3). Justice Stephen Breyer will be 78. Id. 
and the process by which he won confirmation underline the changes in the selection of Justices that we have described.

As we have discussed, the augmented list of twenty-one prospective nominees that Trump announced as a presidential candidate was created primarily by leaders of the Federalist Society. ${ }^{287}$ Gorsuch had established strong conservative credentials through his clerkships for conservative judges, his service in the George W. Bush administration, his involvement in the Federalist Society, and his record as a court of appeals judge. ${ }^{288} \mathrm{He}$ also had the advantages of strong educational credentials, a reputation as a very able judge, and a relatively young age.

In the process that made Gorsuch a finalist for the nomination and ultimately the nominee, Leonard Leo of the Federalist Society played a central role. ${ }^{289}$ An experienced participant in the selection of federal judges, Leo took a leave from the society to assist in the selection of the nominee (and later in his confirmation). From the perspective of the Federalist Society and other people and organizations in the conservative legal movement, all or nearly all the judges on the Trump list would have fit the desired mold rather well. But after a careful vetting process that included multiple interviews of leading candidates, Gorsuch's combination of strengths elevated him above all the other contenders.

In the polarized atmosphere of the confirmation process today, it was certain that nearly all Democratic senators would vote against confirming Gorsuch and equally certain that every Republican senator would vote for him. As we have discussed, judicial confirmation politics exemplify pervasive party polarization; today, the votes of Democratic and Republican Senators on Supreme Court nominees increasingly

\footnotetext{
${ }^{287}$ See note 192 and accompanying text. For a discussion of the Federalist Society's role in vetting Trump nominees, see Lawrence Baum and Neal Devins, Federalist Court, Slate (Jan 31, 2017), available at http://www.slate.com/articles/news_and_politics/jurisprudence/2017/01/how _the_federalist_society_became_the_de_facto_selector_of_republican_supreme.html.

${ }^{288}$ Dylan Matthews, Neil Gorsuch, Donald Trump's Supreme Court Nominee, Explained, Vox (March 20, 2017), available at http://www.vox.com/policy-and-politics/2017/1/31/14450024 /neil-gorsuch-supreme-court.

${ }^{289}$ See Jeffrey Toobin, The Conservative Pipeline to the Supreme Court, New Yorker (April 17, 2017), available at http://www.newyorker.com/magazine/2017/04/17/the-conservative-pipe line-to-the-supreme-court; Eric Lipton and Jeremy W. Peters, In Gorsuch, Conservative Activist Sees Test Case for Reshaping the fudiciary, NY Times (March 18, 2017), available at https://www .nytimes.com/2017/03/18/us/politics/neil-gorsuch-supreme-court-conservatives.html.
} 